\title{
Nocturnal nitrogen oxides at a rural mountain-site in south-western Germany
}

\author{
J. N. Crowley ${ }^{1}$, G. Schuster ${ }^{1}$, N. Pouvesle ${ }^{1}$, U. Parchatka ${ }^{1}$, H. Fischer ${ }^{1}$, B. Bonn ${ }^{2}$, H. Bingemer ${ }^{2}$, and J. Lelieveld ${ }^{1}$ \\ ${ }^{1}$ Max-Planck-Institut für Chemie, Atmospheric Chemistry Dept., Mainz, Germany \\ ${ }^{2}$ Universität Frankfurt, Fachbereich Geowissenschaften, Frankfurt am Main, Germany
}

Received: 11 December 2009 - Published in Atmos. Chem. Phys. Discuss.: 19 January 2010

Revised: 18 March 2010 - Accepted: 18 March 2010 - Published: 25 March 2010

\begin{abstract}
A new, two-channel instrument for simultaneous $\mathrm{NO}_{3}$ and $\mathrm{N}_{2} \mathrm{O}_{5}$ monitoring was used to make the first comprehensive set of nocturnal $\mathrm{NO}_{\mathrm{x}}$ measurements $\left(\mathrm{NO}, \mathrm{NO}_{2}\right.$, $\mathrm{NO}_{3}$ and $\mathrm{N}_{2} \mathrm{O}_{5}$ ) at the Taunus Observatory, a rural mountain site (Kleiner Feldberg) in South-western Germany. In May 2008, $\mathrm{NO}_{3}$ and $\mathrm{N}_{2} \mathrm{O}_{5}$ mixing ratios were well above the instrumental detection limit (a few ppt) on all nights of the campaign and were characterised by large variability. The concentrations of $\mathrm{NO}_{3}, \mathrm{~N}_{2} \mathrm{O}_{5}$ and $\mathrm{NO}_{2}$ were consistent with the equilibrium constant, $K_{2}$, defining the rates of formation and thermal dissociation of $\mathrm{N}_{2} \mathrm{O}_{5}$. A steady-state lifetime analysis is consistent with the loss of nocturnal $\mathrm{NO}_{\mathrm{x}}$ being dominated by the reaction of $\mathrm{NO}_{3}$ with volatile organic compounds in this forested region, with $\mathrm{N}_{2} \mathrm{O}_{5}$ uptake to aerosols of secondary importance. Analysis of a limited dataset obtained at high relative humidity indicated that the loss of $\mathrm{N}_{2} \mathrm{O}_{5}$ by reaction with water vapour is less efficient ( $>$ factor 3 ) than derived using laboratory kinetic data. The fraction of $\mathrm{NO}_{\mathrm{x}}$ present as $\mathrm{NO}_{3}$ and $\mathrm{N}_{2} \mathrm{O}_{5}$ reached $\sim 20 \%$ on some nights, with night-time losses of $\mathrm{NO}_{\mathrm{x}}$ competing with daytime losses.
\end{abstract}

\section{Introduction}

Daytime oxidation processes (e.g. of volatile organic trace gases, VOC) are dominated by the photochemically generated hydroxyl radical $(\mathrm{OH})$, which is present at much reduced levels during the night. At night-time, the nitrate radical, $\mathrm{NO}_{3}$, is considered the major initiator of oxidation of certain classes of gas-phase organic compounds such as biogenic terpenes and dimethyl sulphide (Wayne et al., 1991).

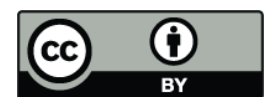

Correspondence to: J. N. Crowley (john.crowley@mpic.de)
$\mathrm{NO}_{3}$ is formed predominantly in the reaction of $\mathrm{NO}_{2}$ with ozone (Reaction R1) and is converted to $\mathrm{N}_{2} \mathrm{O}_{5}$ via further reaction with $\mathrm{NO}_{2}$ (Reaction R2a). Due to the thermal decomposition of $\mathrm{N}_{2} \mathrm{O}_{5}$ to $\mathrm{NO}_{2}$ and $\mathrm{NO}_{3}$ (Reaction $\mathrm{R} 2 \mathrm{~b}$ ), the relative concentrations of $\mathrm{NO}_{3}$ and $\mathrm{N}_{2} \mathrm{O}_{5}$ are closely linked (Brown et al., 2003a) and are a strong function of temperature and $\left[\mathrm{NO}_{2}\right]$.

$$
\begin{aligned}
& \mathrm{NO}_{2}+\mathrm{O}_{3} \rightarrow \mathrm{NO}_{3}+\mathrm{O}_{2} \\
& \mathrm{NO}_{2}+\mathrm{NO}_{3}+\mathrm{M} \rightarrow \mathrm{N}_{2} \mathrm{O}_{5}+\mathrm{M} \\
& \mathrm{N}_{2} \mathrm{O}_{5}+\mathrm{M} \rightarrow \mathrm{NO}_{2}+\mathrm{NO}_{3}+\mathrm{M}
\end{aligned}
$$

As a consequence of its rapid photolysis and reaction with NO (Reaction R4), the $\mathrm{NO}_{3}$ radical is absent or at significantly reduced concentration during the day and the rapid equilibrium (Reactions R2a, R2b) ensures very low concentrations of $\mathrm{N}_{2} \mathrm{O}_{5}$ also. Apart from regions impacted by strong anthropogenic NO emissions or very close to the surface where soil emissions of NO are important, NO is rapidly converted to $\mathrm{NO}_{2}$ via Reaction (R3) at night enabling a build up of $\mathrm{NO}_{3}$ and $\mathrm{N}_{2} \mathrm{O}_{5}$. In rural areas $\mathrm{NO}_{2}, \mathrm{NO}_{3}$ and $\mathrm{N}_{2} \mathrm{O}_{5}$ are thus the only nocturnal nitrogen oxides apart from long lived, reservoir species such as $\mathrm{HNO}_{3}$ or PAN.

$\mathrm{NO}+\mathrm{O}_{3} \rightarrow \mathrm{NO}_{2}+\mathrm{O}_{2}$

$\mathrm{NO}_{3}+\mathrm{NO} \rightarrow 2 \mathrm{NO}_{2}$

The lifetime of $\mathrm{NO}_{3}$ is then controlled mainly by its reactions with certain VOCs, whereas $\mathrm{N}_{2} \mathrm{O}_{5}$ (an acid anhydride) is lost mainly by heterogeneous hydrolysis on aerosol surfaces to result in aqueous phase nitrate formation:

$\mathrm{NO}_{3}+\mathrm{VOC} \rightarrow$ products

$\mathrm{N}_{2} \mathrm{O}_{5}+$ aerosol $\rightarrow$ nitrate

Published by Copernicus Publications on behalf of the European Geosciences Union. 
Close to ground level, dry deposition could also be important for both $\mathrm{NO}_{3}$ and $\mathrm{N}_{2} \mathrm{O}_{5}$.

The sequential oxidation of $\mathrm{NO}$ to $\mathrm{NO}_{2}$ to $\mathrm{NO}_{3}$ to $\mathrm{N}_{2} \mathrm{O}_{5}$ and finally to particulate nitrate thus represents a change in the partitioning of nitrogen oxides between the $\mathrm{NO}_{\mathrm{x}}$ $\left(\mathrm{NO}+\mathrm{NO}_{2}\right)$ and $\mathrm{NO}_{\mathrm{z}}$ families, where $\mathrm{NO}_{\mathrm{z}}$ is the sum of all nitrogen oxides $\left(\mathrm{NO}_{\mathrm{y}}\right)$ minus $\mathrm{NO}_{\mathrm{x}}$. Note that $\mathrm{N}_{2} \mathrm{O}_{5}$ contributes twice to $\mathrm{NO}_{\mathrm{y}}$ as it contains two $\mathrm{N}$-atoms. The heterogeneous loss of $\mathrm{N}_{2} \mathrm{O}_{5}$ or $\mathrm{NO}_{3}$ also modifies the partitioning of $\mathrm{NO}_{\mathrm{y}}$ between the gas and particulate phases. Both the modification of the $\mathrm{NO}_{\mathrm{x}} / \mathrm{NO}_{\mathrm{y}}$ ratio and the oxidation of VOCs by $\mathrm{NO}_{3}$ impact daytime photochemical rates.

Given sufficient time, a stationary state is reached for $\mathrm{NO}_{3}$ at night in which its production (the rate of which is given by $\left.k_{1}\left[\mathrm{NO}_{2}\right]\left[\mathrm{O}_{3}\right]\right)$ is approximately balanced by the sum of direct losses and indirect loss via conversion to $\mathrm{N}_{2} \mathrm{O}_{5}$ and subsequent heterogeneous removal. The turnover lifetime of $\mathrm{NO}_{3}$ in steady state, $\tau_{\mathrm{ss}}\left(\mathrm{NO}_{3}\right)$, which is defined as the inverse of the sum of the direct and indirect loss frequencies $\left(\tau_{\mathrm{ss}}\left(\mathrm{NO}_{3}\right)=1 /\left(f_{\text {dir }}\left(\mathrm{NO}_{3}\right)+f_{\text {indir }}\left(\mathrm{NO}_{3}\right)\right)\right.$, is given by:

$\tau_{\mathrm{ss}}\left(\mathrm{NO}_{3}\right)=\frac{\left[\mathrm{NO}_{3}\right]}{k_{1}\left[\mathrm{NO}_{2}\right] \cdot\left[\mathrm{O}_{3}\right]}$

In the absence of both light and $\mathrm{NO}$ the direct losses of $\mathrm{NO}_{3}$ are dominated by reactions with organic trace gases (Reaction R5) so that, to a good approximation, $f_{\text {dir }}\left(\mathrm{NO}_{3}\right)=\Sigma\left(k_{i}\right.$ $[\mathrm{VOC}]_{i}$ ) where $k_{i}$ is the rate coefficient for reaction of $\mathrm{NO}_{3}$ with a specific VOC of concentration [VOC]. The rate of indirect loss of $\mathrm{NO}_{3}$ via its conversion to $\mathrm{N}_{2} \mathrm{O}_{5}$ depends on the equilibrium constant $\left(K_{2}\right)$ that defines the relative concentration of $\mathrm{NO}_{3}$ and $\mathrm{N}_{2} \mathrm{O}_{5}$ for any given temperature and amount of $\mathrm{NO}_{2}$.

$$
K_{2}=\frac{\left[\mathrm{N}_{2} \mathrm{O}_{5}\right]}{\left[\mathrm{NO}_{2}\right] \cdot\left[\mathrm{NO}_{3}\right]}=\frac{k_{2}}{k_{-2}}
$$

The frequency of indirect loss of $\mathrm{NO}_{3}$ is thus given by $f_{\text {indir }}\left(\mathrm{NO}_{3}\right)=K_{2}\left[\mathrm{NO}_{2}\right]\left(f_{\text {het }}+f_{\text {homo }}\right)$. Where $f_{\text {het }}$ is the loss frequency for $\mathrm{N}_{2} \mathrm{O}_{5}$ due to irreversible, heterogeneous uptake to aerosol surfaces and $f_{\text {homo }}$ is the loss frequency of $\mathrm{N}_{2} \mathrm{O}_{5}$ due to gas-phase reaction with water vapour. Combining the definitions of $f_{\text {dir }}\left(\mathrm{NO}_{3}\right)$ and $f_{\text {indir }}\left(\mathrm{NO}_{3}\right)$ with Eq. (1) and ignoring loss of $\mathrm{NO}_{3}$ or $\mathrm{N}_{2} \mathrm{O}_{5}$ by dry deposition, we derive (Geyer et al., 2001; Aldener et al., 2006):

$$
\begin{aligned}
\tau_{\mathrm{ss}}\left(\mathrm{NO}_{3}\right) & \approx \frac{1}{f_{\text {dir }}\left(\mathrm{NO}_{3}\right)+f_{\text {indir }}\left(\mathrm{NO}_{3}\right)} \\
& \approx \frac{1}{f_{\text {dir }}\left(\mathrm{NO}_{3}\right)+K_{2}\left[\mathrm{NO}_{2}\right]\left(f_{\text {het }}+f_{\text {homo }}\right)}
\end{aligned}
$$

For aerosol particles of diameter less than $\sim 1$ micron, $f_{\text {het }}$ is given by:

$f_{\text {het }} \approx \frac{\gamma \cdot \bar{c} \cdot A}{4}$

where $A$ is the aerosol surface area density $\left(\mathrm{cm}^{2} \mathrm{~cm}^{-3}\right), \bar{c}$ is the mean molecular velocity of $\mathrm{N}_{2} \mathrm{O}_{5}\left(23500 \mathrm{~cm} \mathrm{~s}^{-1}\right.$ at
$280 \mathrm{~K})$ and $\gamma$ is the dimensionless uptake coefficient. The available kinetic data (Atkinson, 2004) indicates a gas-phase reaction between $\mathrm{N}_{2} \mathrm{O}_{5}$ and $\mathrm{H}_{2} \mathrm{O}$ which contains terms both linear and quadratic in $\mathrm{H}_{2} \mathrm{O}$ concentration:

$\mathrm{N}_{2} \mathrm{O}_{5}+\mathrm{H}_{2} \mathrm{O} \rightarrow 2 \mathrm{HNO}_{3}$
$\mathrm{~N}_{2} \mathrm{O}_{5}+2 \mathrm{H}_{2} \mathrm{O} \rightarrow 2 \mathrm{HNO}_{3}+\mathrm{H}_{2} \mathrm{O}$

with $k_{7 \mathrm{a}}=2.5 \times 10^{-22} \mathrm{~cm}^{3}$ molecule ${ }^{-1} \mathrm{~s}^{-1}$ and $k_{7 \mathrm{~b}}$ $=1.8 \times 10^{-39} \quad\left[\mathrm{H}_{2} \mathrm{O}\right] \mathrm{cm}^{3}$ molecule ${ }^{-1} \mathrm{~s}^{-1}$. As $\left[\mathrm{H}_{2} \mathrm{O}\right] \gg$ $\left[\mathrm{N}_{2} \mathrm{O}_{5}\right]$, pseudo first-order kinetics are applicable so that

$f_{\text {homo }}=k_{7 \mathrm{a}}\left[\mathrm{H}_{2} \mathrm{O}\right]+k_{7 \mathrm{~b}}\left[\mathrm{H}_{2} \mathrm{O}\right]^{2}$

with the $\mathrm{H}_{2} \mathrm{O}$ concentration in units of molecule $\mathrm{cm}^{-3}$. Recent field measurements (Brown et al., 2006, 2009) have cast doubt on the accuracy of the laboratory studies, suggesting that the reaction proceeds significantly slower (see later).

The relative importance of direct and indirect loss mechanisms for $\mathrm{NO}_{3}$ depends on several factors including the concentrations of $\mathrm{NO}_{2}$ and VOCs, the available surface area $(A)$ and the temperature, which strongly influences $K_{2}$, emission rates of biogenic VOCs (Geyer and Platt, 2002) and available $\mathrm{H}_{2} \mathrm{O}$-vapour. For this reason, the direct and indirect loss mechanisms can show large regional and seasonal dependencies, with $\mathrm{NO}_{3}$ lifetimes close to the surface varying from minutes in areas impacted by anthropogenic or biogenic emissions to hours in remote regions (Heintz et al., 1996; Allan et al., 2000).

In this paper we describe the first deployment of a new, two-channel optical cavity based instrument for detection of $\mathrm{NO}_{3}$ and $\mathrm{N}_{2} \mathrm{O}_{5}$, and also the first measurements of $\mathrm{NO}_{3}$ or $\mathrm{N}_{2} \mathrm{O}_{5}$ at the Taunus Observatory, a rural mountain site in South-western Germany. Ancillary measurements of NO, $\mathrm{NO}_{2}, \mathrm{O}_{3}$ and aerosol surface area enabled us to calculate $\mathrm{NO}_{3}$ and $\mathrm{N}_{2} \mathrm{O}_{5}$ lifetimes and assess some aspects of nocturnal chemistry at this site.

\section{Experimental}

\subsection{Site description}

The measurements were made at the Taunus Observatory, located at $50^{\circ} 13^{\prime} 25^{\prime \prime} \mathrm{N}, 8^{\circ} 26^{\prime} 56^{\prime \prime} \mathrm{E}$ and $825 \mathrm{~m}$ above sea level at the summit of the "Kleiner Feldberg" a mountain in the Taunus range in South-western Germany (Fig. 1). The area directly around the observatory is mainly coniferous forest (predominantly spruce). The hill top itself (50 $\mathrm{m}$ in radius) has been cleared of trees for meteorological measurements several times, the last time about half a century ago and only a couple of willows and some birch trees remain between the cleared area and the spruce trees. The direct vicinity of the measurement containers is covered by shrubs and blueberry plants. Because of its elevation the station is known for its quite remote character for central Germany with a 

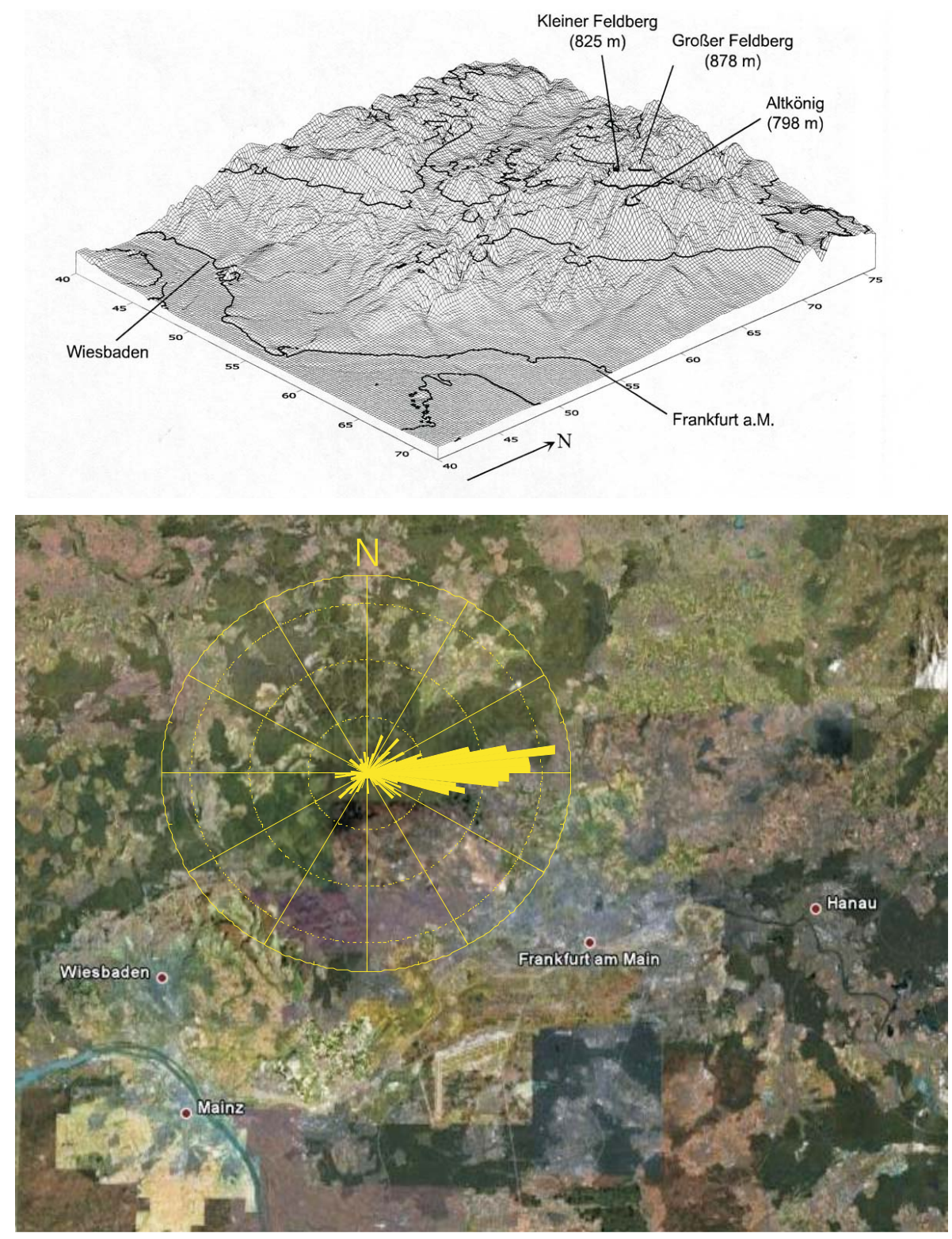

Fig. 1. Upper: Topographic map indicating the location of the Taunus Observatory at the summit of the Kleiner Feldberg (from PhD thesis of G. M. Handisides). Lower: Relation of site to local cites indicating predominant wind directions during the campaign.

few main roads and some small towns within $5 \mathrm{~km}$. The observatory is impacted by pollution from the heavily populated Rhein-Main area (pop. $\sim 2$ million) including a dense motorway system and large cities such as Frankfurt (pop. $\sim 700000,30 \mathrm{~km} \mathrm{SE}$ ), Wiesbaden (pop. $\sim 300000,20 \mathrm{~km}$ SW) and Mainz (pop. $\sim 200000,25 \mathrm{~km} \mathrm{SSW}$ ). The area 50$100 \mathrm{~km}$ north of Kleiner Feldberg is lightly populated and devoid of major industry. Wind flow patterns are influenced by the presence of two similar sized mountains: Altkönig $(798 \mathrm{~m})$ and Großer Feldberg $(878 \mathrm{~m})$ in the direct vicinity ( $2.7 \mathrm{~km}$ and $1.3 \mathrm{~km}$ distant, respectively). Previous measurements have shown that highest $\mathrm{CO}$ levels at the Taunus $\mathrm{Ob}$ - servatory were associated with Easterly winds containing air from the Frankfurt region which have been channelled between the Großer Feldberg and Altkönig mountains (Wetter, 1998) with highest levels of $\mathrm{O}_{3}$ arriving with wind from the east to southeast during warm, sunny periods (Handisides, 2001). As well as the Taunus Observatory, the meteorological garden of the German weather service (DWD) and the measurement container of the State of Hessen environmental agency (HLUG) are also located at the summit of the Kleiner Feldberg. 


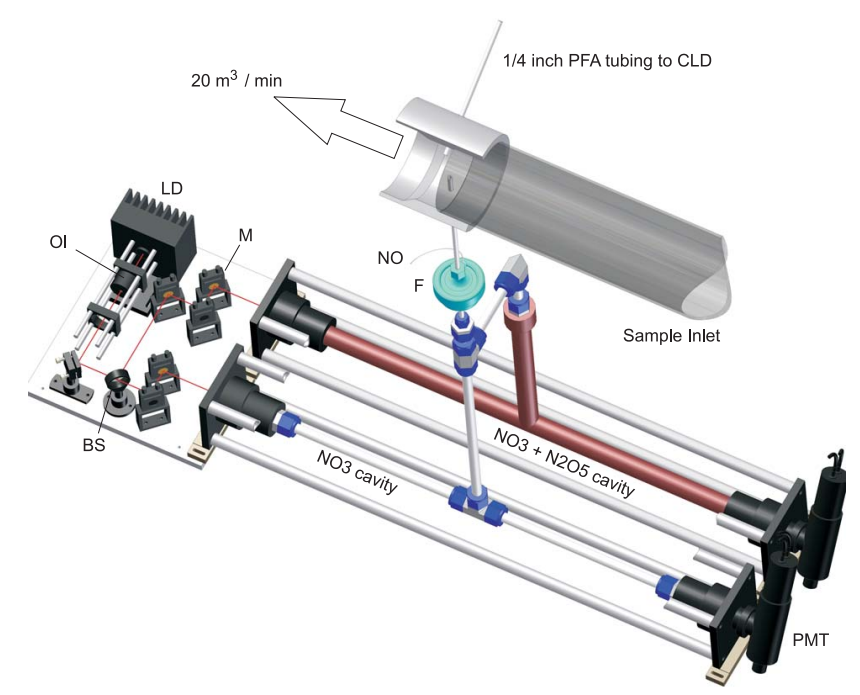

Fig. 2. Two-channel $\mathrm{NO}_{3} / \mathrm{N}_{2} \mathrm{O}_{5}$ instrument. The sample inlet was a $1.4 \mathrm{~m}$ long Teflon coated glass tube (ID $104 \mathrm{~mm}$ ). Gas was sampled from the centre of the tube to the $\mathrm{NO}_{3} / \mathrm{N}_{2} \mathrm{O}_{5}$ and $\mathrm{NO} / \mathrm{NO}_{2} / \mathrm{O}_{3}$ instruments and exits close to the cavity mirrors as described in detail by Schuster et al. (2009). The $\mathrm{NO}_{3}$ cavity was made of PFA tubing and fittings (thermal insulation not shown), the $\mathrm{N}_{2} \mathrm{O}_{5}+\mathrm{NO}_{3}$ cavity was made of Teflon (FEP) coated glass (heating elements and insulation not shown). $\mathrm{NO}=\mathrm{NO}$ addition point for $\mathrm{NO}_{3}$ titration. $\mathrm{F}=\mathrm{PFA}$ filter folder with $2 \mu \mathrm{m}$ PTFE filter. $\mathrm{OI}=$ optical isolator. $\mathrm{BS}=$ beam splitter $\left(70 \%\right.$ for $\mathrm{NO}_{3}$ cavity, $30 \%$ for $\mathrm{NO}_{3}+\mathrm{N}_{2} \mathrm{O}_{5}$ channel). PMT=housing with photomultiplier and interference filter. $\mathrm{M}=$ Aluminium coated mirror. $\mathrm{LD}=\mathrm{Laser}$ diode in temperature controlled housing. $\mathrm{CLD}=$ chemiluminescence instrument for $\mathrm{NO}$, $\mathrm{NO}_{2}$ and $\mathrm{O}_{3}$.

\subsection{Instrumentation}

The instruments were located in the upper container of a twocontainer tower, with the inlet $\sim 4.5 \mathrm{~m}$ above the ground. In order to avoid trace gas losses (especially of $\mathrm{NO}_{3}$ ) the inlet was constructed from a $1.4 \mathrm{~m}$ long, glass tube of internal diameter $10.4 \mathrm{~cm}$, which was internally coated with a thin film of Teflon (FEP 100a). An industrial fan attached to the exit of the glass tube maintained a flow (at circa 700 Torr) of $\sim 20 \mathrm{~m}^{3} \mathrm{~min}^{-1}$ through the tube, resulting in residence times of $\sim 0.1 \mathrm{~s}$ to the sampling line. $18 \mathrm{~L} \mathrm{~min}^{-1}$ air was sampled (at $90^{\circ}$ to the main flow) from the centre of the large diameter tube via a short piece of $1 / 4^{\prime \prime}$ PFA-Teflon tubing $(\sim 15 \mathrm{~cm})$ and a $2 \mu \mathrm{m}$ pore Teflon filter to the $\mathrm{NO}_{3} / \mathrm{N}_{2} \mathrm{O}_{5}$ instrument. An $\sim 4 \mathrm{~m}$ length of $1 / 4^{\prime \prime}$ PFA-Teflon tubing, sampling at $\sim 3 \mathrm{~L} / \mathrm{min}$ from the centre of the inlet, transferred air to the $\mathrm{NO} / \mathrm{NO}_{2} / \mathrm{O}_{3}$ detector (see below). Physical characterisation of the aerosol size distribution and aerosol number concentration was performed via inlets from the same container used for $\mathrm{NO}_{3}$ and $\mathrm{N}_{2} \mathrm{O}_{5}$ measurements. Smaller particles were sampled through a $1 \mathrm{~m}$ long Tygon tube, which was mounted horizontally straight out of the container window in order to keep sampling losses as small as possible.
Larger particles were sampled via a vertical glass tube extending above the roof of the upper container. This inlet was covered by a cap to prevent rain from entering.

\subsection{1 $\mathrm{NO}_{3}$ and $\mathrm{N}_{2} \mathrm{O}_{5}$ measurements}

$\mathrm{NO}_{3}$ and $\mathrm{N}_{2} \mathrm{O}_{5}$ mixing ratios were measured using a twochannel, off axis cavity-ring-down system (OA-CRD). A single channel prototype of this device was described recently (Schuster et al., 2009) and took part in a major $\mathrm{NO}_{3} / \mathrm{N}_{2} \mathrm{O}_{5}$ inter-comparison at an environmental chamber in 2007 (Apodaca et al., 2009; Dorn et al., 2010). The major modification of the device for the present campaign was the introduction of a second cavity to enable simultaneous measurement of $\mathrm{NO}_{3}$ and $\mathrm{N}_{2} \mathrm{O}_{5}$. This is the first implementation of the twochannel device in the field and it is therefore described in some detail.

The instrument and inlet configuration is shown in Fig. 2. The $\mathrm{NO}_{3}$ cavity (PFA tubing, resonator length $70 \mathrm{~cm}$, volume $79 \mathrm{~cm}^{3}$ ) was operated close to ambient temperature, whereas the summed concentration of $\mathrm{NO}_{3}+\mathrm{N}_{2} \mathrm{O}_{5}$ was measured in a Teflon coated Pyrex cavity (resonator length $70 \mathrm{~cm}$, volume $165 \mathrm{~cm}^{3}$ ) heated to $80^{\circ} \mathrm{C}$. The heated cavity was located behind a $\sim 20 \mathrm{~cm}$ section of Teflon coated glass tubing heated to $85^{\circ} \mathrm{C}$ to quantitatively convert $\mathrm{N}_{2} \mathrm{O}_{5}$ to $\mathrm{NO}_{3}$. Laboratory tests showed that, at the given flow rate and residence time in the converter, this temperature was sufficient to quantitatively dissociate $\mathrm{N}_{2} \mathrm{O}_{5}$. Note that the cavity temperature was cooler than in our prototype device, (Schuster et al., 2009) which was operated at $95^{\circ} \mathrm{C}$. The flow rates through the cavities were $10 \mathrm{~L}(\mathrm{std}) \mathrm{min}^{-1}\left(\mathrm{NO}_{3}\right)$ and $8 \mathrm{~L}(\mathrm{std}) \mathrm{min}^{-1}$ $\left(\mathrm{N}_{2} \mathrm{O}_{5}+\mathrm{NO}_{3}\right)$, resulting in residence times of $\sim 0.4 \mathrm{~s}$ and $0.8 \mathrm{~s}$, respectively.

The light source used was a $\sim 100 \mathrm{~mW}$ laser diode operated at $662 \mathrm{~nm}$, close to the peak of the $\mathrm{NO}_{3}$ absorption spectrum. The laser current was modulated to broaden the laserspectral bandwidth and improve the signal/noise ratio of the cavity emission, without loss of overlap with the broad $\mathrm{NO}_{3}$ spectrum (Schuster et al., 2009). Light exiting the cavity was filtered by a $662 \mathrm{~nm}$ interference filter prior to detection by a PMT. The pre-amplified PMT signal was digitised and averaged with a $10 \mathrm{MHz}, 12$ bit USB scope (Picoscope 3424) which was triggered at the laser modulation frequency of $100 \mathrm{~Hz}$. Typically 256 ring-down events were recorded to result in a time resolution of $\sim 3 \mathrm{~s}$. The cavity loss due to absorption at $662 \mathrm{~nm}$ was calculated from the change in ringdown constant in the presence of an absorber and converted to a concentration of $\mathrm{NO}_{3}$ using the effective cross section of $\mathrm{NO}_{3}$ at the experimental temperature and the established relation (Berden et al., 2000; Mazurenka et al., 2005)

$\left[\mathrm{NO}_{3}\right]=\frac{\Delta k_{\mathrm{rd}} L}{\sigma_{\mathrm{NO} 3} c d}$

where $\left[\mathrm{NO}_{3}\right]$ is the concentration of $\mathrm{NO}_{3}\left(\right.$ molecule $\left.\mathrm{cm}^{-3}\right)$, $k_{\mathrm{rd}}$ is the ring-down constant (a first-order rate coefficient 
with units of $\left.\mathrm{s}^{-1}\right), \Delta k_{\mathrm{rd}}$ is the difference in the ring-down decay constant with and without $\mathrm{NO}_{3}, L$ is the distance between the cavity mirrors $(70 \mathrm{~cm}), d$ is the length of the cavity which is filled with absorber, $\sigma_{\mathrm{NO} 3}$ is the effective absorption cross section of $\mathrm{NO}_{3}$ and $c$ is the speed of light $\sim 2.998 \times 10^{10} \mathrm{~cm} \mathrm{~s}^{-1}$ ). Temperature dependent values of $\sigma_{\mathrm{NO} 3}$ have been determined by Yokelson et al. (1994) and Osthoff et al. (2007). The parameterisations of Orphal et al. (2003) and Osthoff et al. (2007) both give a value of $1.77 \times 10^{-17} \mathrm{~cm}^{2}$ molecule ${ }^{-1}$ at the peak of the $662 \mathrm{~nm}$ band at $80^{\circ} \mathrm{C}$. This value was convoluted with the laser emission profile to obtain effective cross sections as described previously (Schuster et al., 2009).

The ring-down constant in the absence of $\mathrm{NO}_{3}$ was derived by adding $\sim 10^{12}$ molecule $\mathrm{cm}^{-3}$ of $\mathrm{NO}(8 \mathrm{sccm}$ of a $100 \mathrm{ppm}$ mixture of $\mathrm{NO}$ in $\mathrm{N}_{2}$ ) to the air above the filter every $100 \mathrm{~s}$ for a period of $\sim 20 \mathrm{~s}$ (duty cycle of $80 \%$ ). Slight drifts in the ring-down constant over the course of an hour were then removed from the dataset by fitting a polynomial to the $\sim 36$ titration points obtained in the presence of NO. Typically, for the $\mathrm{NO}_{3}$ channel the standard deviation in the fit was $\sim 1 \mathrm{ppt}$, whereas for the sum channel it was $\sim 2.5$ ppt.

By variation of the mirror purge gas flow whilst monitoring the ring-down signal due to a constant flow of $\mathrm{NO}_{2}$ into the cavity $\left(\mathrm{NO}_{2}\right.$ also absorbs at $\left.662 \mathrm{~nm}\right)$, we were able to calculate a value of $L / d$ of $1.01 \pm 0.03$. Note that the ring-down time constant, $\tau$, is equal to $1 / k_{\mathrm{rd}}$ and for a cavity free of absorbing species was typically close to $80 \mu$ s, indicating an effective optical path length of $\sim 25 \mathrm{~km}$.

Loss of $\mathrm{NO}_{3}$ to the filter was determined in the laboratory as described previously (Schuster et al., 2009) by flowing $\mathrm{NO}_{3}$ or $\mathrm{N}_{2} \mathrm{O}_{5}$ (generated in the reaction of $\mathrm{NO}_{2}$ with $\mathrm{O}_{3}$ ) into the cavities with and without a filter in place. Repeated tests resulted in a clean filter transmission of $90 \pm 3 \%$ for $\mathrm{NO}_{3}$ and $98 \pm 2 \%$ for $\mathrm{N}_{2} \mathrm{O}_{5}$. During the campaign, the filter was usually changed at $1 \mathrm{~h}$ intervals to prevent significant build up of a reactive surface. We show later that leaving the filter for two hours did on one occasion result in loss of $\mathrm{NO}_{3}$ transmission (but not $\mathrm{N}_{2} \mathrm{O}_{5}$ ).

The data also required correction for loss of $\mathrm{NO}_{3}$ during transport through the cavities. This was achieved by carrying out pre- and post-campaign experiments in the laboratory in which a 11 SLM flow of air containing stable concentrations of $\mathrm{N}_{2} \mathrm{O}_{5}$ and $\mathrm{NO}_{3}$ was passed through both cavities. By varying the relative flow rate through each cavity whilst maintaining the total flow and thus $\mathrm{NO}_{3} / \mathrm{N}_{2} \mathrm{O}_{5}$ concentration, the residence time of gas in each cavity was varied. As described previously (Schuster et al., 2009) an exponential dependence of the $\mathrm{NO}_{3}$ signal on residence time was observed, allowing loss terms of $0.25 \pm 0.05 \mathrm{~s}^{-1}$ (cold cavity) and $0.11 \pm 0.05 \mathrm{~s}^{-1}$ (hot cavity) to be derived. Based on known cavity residence times when sampling from the atmosphere, the corrections to the field data for cavity losses were calculated as $11 \pm 2 \%$ for both channels.
Other corrections that can be applied to the data result from chemistry within the cavities. The addition of NO to titrate $\mathrm{NO}_{3}$ whilst measuring the ring-down constant in the absence of $\mathrm{NO}_{3}$ (chemical zero) disturbs the equilibrium between $\mathrm{NO}_{3}$ and $\mathrm{N}_{2} \mathrm{O}_{5}$, and leads to $\mathrm{N}_{2} \mathrm{O}_{5}$ dissociation to $\mathrm{NO}_{3}$. The magnitude of this effect (essentially an error in the determination of the chemical zero) can be estimated in a steady state analysis from the amount of $\mathrm{N}_{2} \mathrm{O}_{5}$, the cavity temperature and the $\mathrm{NO}$ added as:

$\left[\mathrm{NO}_{3}\right]_{\text {extra }}=\frac{k_{-2}\left[\mathrm{~N}_{2} \mathrm{O}_{5}\right]}{k_{4}[\mathrm{NO}]}$

At a typical cavity temperature of $292 \mathrm{~K}, k_{-2}$ is $\sim 0.02 \mathrm{~s}^{-1}$ and $k_{4}$ is $3.6 \times 10^{-11} \mathrm{~cm}^{3}$ molecule ${ }^{-1} \mathrm{~s}^{-1}$. The extra $\mathrm{NO}_{3}$ formed in this process is $\sim 0.2 \mathrm{ppt}$ at $\mathrm{N}_{2} \mathrm{O}_{5}$ mixing ratios of 200 ppt. As such $\mathrm{N}_{2} \mathrm{O}_{5}$ mixing ratios were always associated with $\mathrm{NO}_{3}$ mixing ratios of $20 \mathrm{ppt}$ or more, this represents an insignificant effect (sub percent).

In addition to titrating $\mathrm{NO}_{3}$, the addition of $\mathrm{NO}$ can lead to $\mathrm{NO}_{2}$ formation via its reaction with ambient $\mathrm{O}_{3}$. As both $\mathrm{NO}_{2}$ and $\mathrm{O}_{3}$ absorb weakly at $662 \mathrm{~nm}$, (cross sections are $\sim 2 \times 10^{-21} \mathrm{~cm}^{2}$ molecule ${ }^{-1}$ for $\mathrm{NO}_{2}$ and $1 \times 10^{-21} \mathrm{~cm}^{2}$ molecule ${ }^{-1}$ for $\mathrm{O}_{3}$ ) this can also have an impact on the retrieved chemical zero. The amount of $\mathrm{NO}_{2}$ formed during titration, $\delta\left[\mathrm{NO}_{2}\right]$, may be approximated by:

$\delta\left[\mathrm{NO}_{2}\right]=\left[\mathrm{O}_{3}\right]\left\{1-\exp ^{\left(-k_{3} \cdot[\mathrm{NO}] \cdot t\right)}\right\}$

where $t$ is the cavity residence time $\left(0.88 \mathrm{~s}\right.$ in the $\mathrm{N}_{2} \mathrm{O}_{5}+\mathrm{NO}_{3}$ cavity and $0.44 \mathrm{~s}$ in the $\mathrm{NO}_{3}$ cavity). $k_{3}$ is equal to $4.3 \times 10^{-14} \mathrm{~cm}^{3}$ molecule ${ }^{-1} \mathrm{~s}^{-1}$ at $80^{\circ} \mathrm{C}$ (hot cavity) and $1.8 \times 10^{-14} \mathrm{~cm}^{3}$ molecule ${ }^{-1} \mathrm{~s}^{-1}$ at $\sim 290 \mathrm{~K}$ (cold cavity). We assume $\mathrm{O}_{3}$ is $80 \mathrm{ppb}$ (the largest value measured in the campaign). For the hot cavity $\delta \mathrm{NO}_{2}=3 \mathrm{ppb}$, and for the cold cavity just $0.6 \mathrm{ppb}$. Given the values of the $\mathrm{NO}_{2}$ and $\mathrm{O}_{3}$ cross sections listed above, this represents an error of just $0.15 \mathrm{ppt}$ equivalents $\left(\mathrm{N}_{2} \mathrm{O}_{5}+\mathrm{NO}_{3}\right.$ cavity) and $0.03 \mathrm{ppt}\left(\mathrm{NO}_{3}\right.$ cavity $)$ which are much lower than noise levels and fluctuations in the chemical zero.

Although the cold cavity was heavily insulated, we measured temperatures within the cavity that were $\sim 4-5{ }^{\circ} \mathrm{C}$ warmer than ambient. A warming of the cavity compared to ambient air can potentially impact on the $\mathrm{NO}_{3}$ measurement as a new equilibrium between $\mathrm{N}_{2} \mathrm{O}_{5}$ and $\mathrm{NO}_{3}$ may be established, leading to an overestimation of the true $\mathrm{NO}_{3}$ concentration and also the $\mathrm{NO}_{3} / \mathrm{N}_{2} \mathrm{O}_{5}$ ratio. As a first approximation, an upper limit to the size of this effect can be estimated from the concentration of $\mathrm{N}_{2} \mathrm{O}_{5}$, the known dissociation rate constant $\left(k_{-2}\right)$ at the temperature of the cavity and the average residence time $(t)$ of $\mathrm{N}_{2} \mathrm{O}_{5}$ in the cavity.

$\delta\left[\mathrm{NO}_{3}\right]=\left[\mathrm{N}_{2} \mathrm{O}_{5}\right]_{0}\left(1-\exp \left(-k_{-2} t\right)\right)$

At $290 \mathrm{~K}$ (typical ambient temperatures were $280-285 \mathrm{~K}$ ), the thermal dissociation rate constant for $\mathrm{N}_{2} \mathrm{O}_{5}$ is $1.4 \times 10^{-2} \mathrm{~s}^{-1}$. The average residence time is taken as the 
time for gas to be transported half way between the T-piece connector to the centre of the cavity and the exit and is $\sim 0.26 \mathrm{~s}$. This estimation of the residence time takes into account the fact that we "integrate" the $\mathrm{NO}_{3}$ concentration over the entire cavity length. These values of $k_{-2}$ and $t$ result in $\sim 0.4 \%$ conversion of the $\mathrm{N}_{2} \mathrm{O}_{5}$ to $\mathrm{NO}_{3}$, which represents a maximum correction of 1.6 pt for $\mathrm{NO}_{3}$ when $\mathrm{N}_{2} \mathrm{O}_{5}$ was close to $400 \mathrm{ppt}$ (the largest values measured in the campaign). This calculation does not take into account the fact that the formation and loss rates of $\mathrm{N}_{2} \mathrm{O}_{5}$ are not de-coupled at this temperature. As typical vales of $\mathrm{NO}_{2}$ were $1-2 \mathrm{ppb}$ $\left(\sim 2-4 \times 10^{10}\right.$ molecule $\left.\mathrm{cm}^{-3}\right)$ the instantaneous first-order constant for $\mathrm{N}_{2} \mathrm{O}_{5}$ formation $\left(k_{2}\left[\mathrm{NO}_{2}\right]\right)$ is $2.5-5 \times 10^{-2} \mathrm{~s}^{-1}$, i.e. similar to its thermal dissociation rate constant. More accurate correction factors were thus obtained by numerical simulation (Curtis and Sweetenham, 1987) of the effect of a $5{ }^{\circ} \mathrm{C}$ temperature jump in $\mathrm{NO}_{2} / \mathrm{NO}_{3} / \mathrm{N}_{2} \mathrm{O}_{5}$ mixtures at equilibrium and at similar concentrations to those measured in the campaign. The results showed that the maximum change in $\mathrm{NO}_{3}$ or the $\mathrm{NO}_{3} / \mathrm{N}_{2} \mathrm{O}_{5}$ ratio was $\sim 1-1.5 \%$. This effect was considered too small to warrant correction to the data, though it is worth noting that long cavity residence times and larger temperature increases between ambient and cavity will result in significant systematic overestimation of $\mathrm{NO}_{3}$ under some conditions.

The random noise limited detection limits ( $3 \mathrm{~s}$ integration per datapoint) were 1-2 ppt $\left(\mathrm{NO}_{3}\right)$ and 4-5 ppt $\left(\mathrm{N}_{2} \mathrm{O}_{5}\right)$. As summarised by Schuster et al. (2009), when considering the above and taking into account estimated errors in the $\mathrm{NO}_{3}$ cross section at both cavity temperatures we estimate the uncertainty $(2 \sigma)$ to be $\pm 15 \%$ for $\mathrm{NO}_{3}$ and at least 2 ppt. For the $\mathrm{N}_{2} \mathrm{O}_{5}$ channel these values are $\pm 15 \%$ and at least 3 ppt.

\subsection{2 $\mathrm{NO}, \mathrm{NO}_{2}$ and $\mathrm{O}_{3}$ measurements}

The measurements of $\mathrm{NO}, \mathrm{NO}_{2}$ and $\mathrm{O}_{3}$ were based on the chemiluminescence of the reaction between $\mathrm{NO}$ and $\mathrm{O}_{3}$ (Fontijn et al., 1970). The instrument is a modified commercial Chemiluminescence Detector (CLD 790 SR) originally manufactured by ECO Physics (Duernten, Switzerland). The original instrument housed two CLD channels, that were used for the detection of $\mathrm{NO}$ and $\mathrm{NO}_{2}$. The quantitative detection of $\mathrm{NO}_{2}$ is based on its photolytic conversion (Blue Light Converter, Droplet Measurement Technologies, Boulder, Co, USA) to NO, which was subsequently detected in the CLD (Kley and McFarland, 1980). A third channel was added for the measurements of $\mathrm{O}_{3}$ following the design described by Ridley et al. (1992). In the present study data were obtained at a time resolution of $2 \mathrm{~s}$.

In-field calibrations for NO were made on a regular basis by adding a secondary standard ( 2 ppmv $\mathrm{NO}$ in $\mathrm{N}_{2}$, Air Liquide, Germany) diluted by zero air to a mixing ratio of approximately $2 \mathrm{ppbv}$. The zero air, that was also used for regular background measurements, was produced from synthetic air (Air Liquide, Germany), that was additionally fil- tered through a catalytic air purifier $(\mathrm{Pt} / \mathrm{Pd})$ and charcoal and "Purafil" $\left(\mathrm{KMnO}_{4} / \mathrm{Al}_{2} \mathrm{O}_{3}\right)$ cartridges. The secondary $\mathrm{NO}$ standard used in the field was traced to a primary standard (NIST, USA). The efficiency of the Blue Light Converter for $\mathrm{NO}_{2}$ measurements was determined by gas phase titration of NO (from the secondary standard) using an excess of $\mathrm{O}_{3}$. This procedure yielded a conversion efficiency of $(46.6 \pm 2) \%$ over the campaign. The ozone channel was calibrated using a commercial $\mathrm{O}_{3}$ calibrator (model TE49C, Thermo Instruments, Germany).

The detection limits (based on reproducibility of zero measurements) for the $\mathrm{NO}$ and $\mathrm{NO}_{2}$ measurements were $10 \mathrm{ppt}$ and $80 \mathrm{ppt}$, respectively for an integration period of $2 \mathrm{~s}$. The total uncertainties $(2 \sigma)$ for the measurements of $\mathrm{NO}, \mathrm{NO}_{2}$, and $\mathrm{O}_{3}$ were determined to be $10 \%, 10 \%$ and $5 \%$, respectively, based on the reproducibility of in-field background measurements, calibrations, the uncertainties of the standards and the conversion efficiency of the photolytic converter.

\subsubsection{Particle measurements}

Aerosol number and size distribution was monitored using a scanning mobility particle sizer (TSI 3936), consisting of an electrostatic classifier with a ${ }^{80} \mathrm{Kr}$ source for particle equilibrium charging and a long differential mobility analyser (TSI 3081) with a condensation particle counter (TSI 3025A) for particle detection. The sheath flow inside the electrostatic classifier was set to $6 \mathrm{~L} \mathrm{~min}^{-1}$ and the sample flow of the ultra fine particle counter was set to its maximum value of $1.5 \mathrm{~L} \mathrm{~min}^{-1}$ (high flow). This set-up allowed particle detection within the size range between 9.8 and $\sim 300 \mathrm{~nm}$ in diameter. Each size distribution measurement took 135 s, i.e. $120 \mathrm{~s}$ for up scan and $15 \mathrm{~s}$ for down scan. Four consecutive measurements were averaged afterwards to obtain a smooth result with a time resolution of ten minutes. In the absence of information regarding composition, a particle density of $1.2 \mathrm{~g} \mathrm{~cm}^{-3}$ was assumed. Larger particles with a diameter between $360 \mathrm{~nm}$ and $19 \mu \mathrm{m}$ were detected occasionally by an aerosol particle sizer (APS, TSI 3321) using a sampling flow rate of $1 \mathrm{~L} \mathrm{~min}^{-1}$. Typical night-time particle concentrations as measured by the SMPS were 2000-5000 particle $\mathrm{cm}^{-3}$ with a bi-modal distribution (maxima at $\sim 35$ and $120 \mathrm{~nm}$ ) with most surface area (typically $10^{-6} \mathrm{~cm}^{2} \mathrm{~cm}^{-3}$ ) contained in particles of radius $\sim 200-250 \mathrm{~nm}$. The APS particle measurements only functioned sporadically and revealed low concentrations of coarse particles (10-20 particle $\mathrm{cm}^{-3}$, with a mean diameter $\sim 600 \mathrm{~nm}$ ). The APS measurements indicate that particles measured by the SMPS account for at least $65 \%$ of the total aerosol surface area and generally close to $80 \%$. 

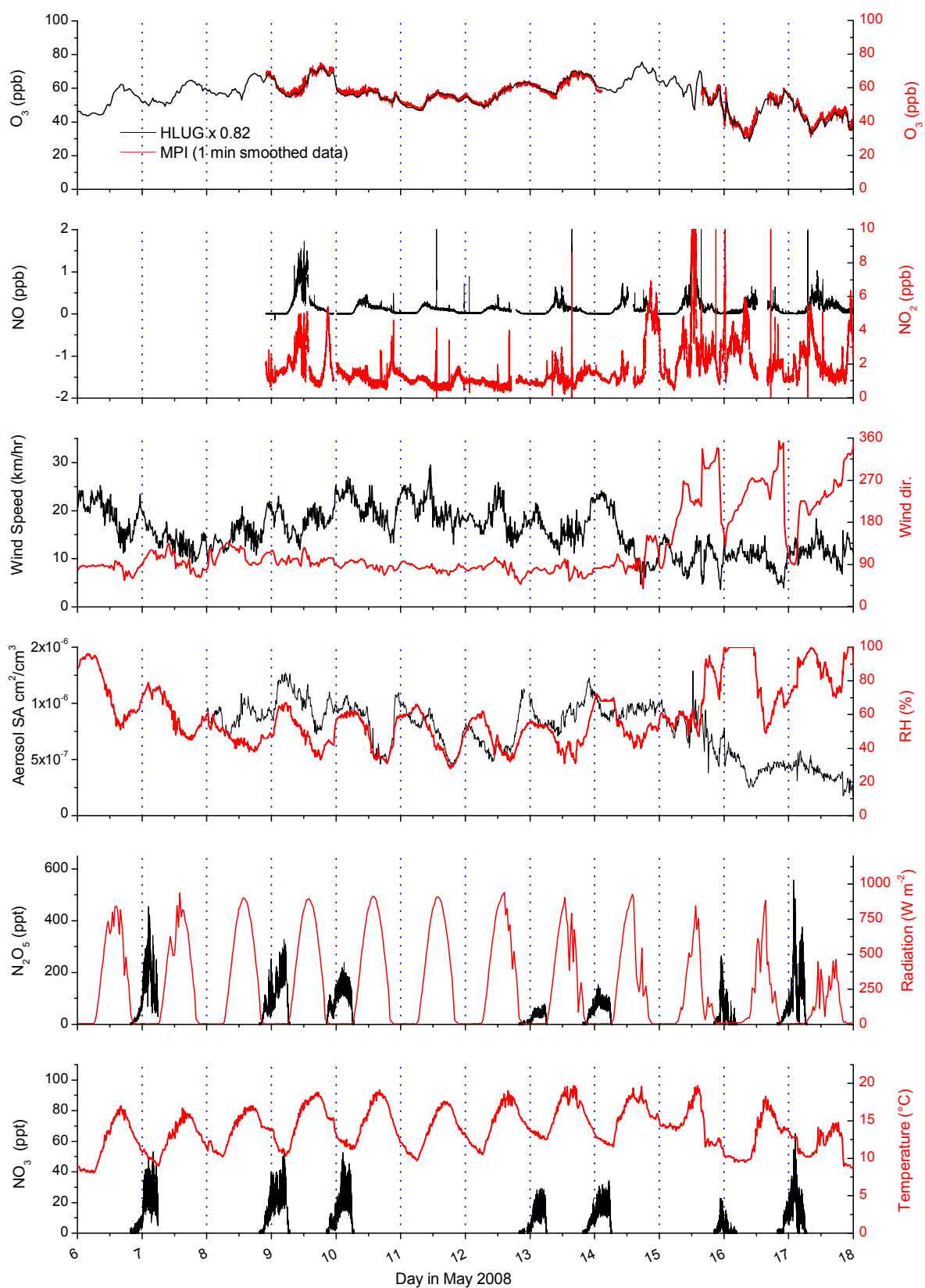

Fig. 3. Trace gas and meteorological overview. Temperature, wind speed and relative humidity were taken measured by the German weather service. Global radiation and wind direction were measured by the Hessen environmental agency (HLUG) who also monitored $\mathrm{O}_{3}$. The HLUG $\mathrm{O}_{3}$ values have been scaled by a factor 0.82 to bring them into line with the MPI measurements.

\subsubsection{Meteorological data}

Atmospheric pressure and temperature, wind direction/speed and relative humidity were available as $10 \mathrm{~min}$ averaged data from the German weather service station (DWD), located $\sim 20 \mathrm{~m}$ away from the container. Global radiation was available from the local environmental agency station (HLUG) as $30 \mathrm{~min}$ averaged data. These measurements were also located just a few metres away. The HLUG also provided $\mathrm{O}_{3}$ measurements (30 min averages) using a UV-absorption instrument (API 400).

\section{Observations and analysis}

The measurements were carried out in May 2008, with almost complete coverage for $\mathrm{NO}$ and $\mathrm{NO}_{2}$ from the 9th until the 20th. $\mathrm{O}_{3}$ was measured over the same period, but with a break for instrument repair between the 14th and 15th. The 

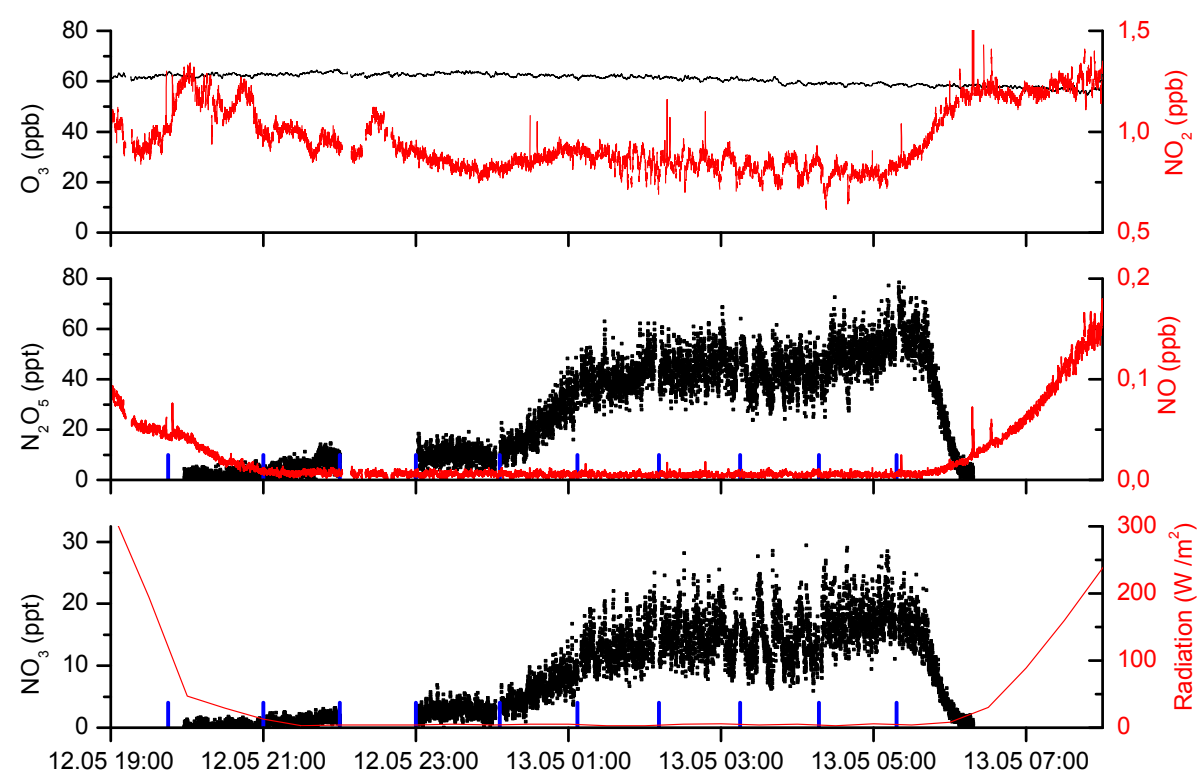

Fig. 4. Data from 12th-13th as exemplary night-time dataset. Great variability in the $\mathrm{NO}_{3}$ and $\mathrm{N}_{2} \mathrm{O}_{5}$ mixing ratios is apparent. The approximate time of local sunrise and sunset may be obtained from the half-hourly measurements of global radiation at the site.

$\mathrm{NO}_{3} / \mathrm{N}_{2} \mathrm{O}_{5}$ instrument was operated on one night prior to and 6 nights within this period. The complete trace gas and meteorological data set is displayed in Fig. 3. $\mathrm{NO}_{3} / \mathrm{N}_{2} \mathrm{O}_{5}$ measurements typically started just before local sunset and stopped after the signals had returned to baseline levels following sunrise. The early part of the campaign (up to 15 May) was characterised by easterly winds $\left(12-25 \mathrm{~km} \mathrm{~h}^{-1}\right)$ cloud-free skies and daytime maximum temperatures up to $18^{\circ} \mathrm{C}$. Temperatures at night generally sunk to $\sim 9-12^{\circ} \mathrm{C}$ with relative humidities of $30-45 \%$ and no precipitation. After 15 May, the wind direction was more variable with components from the Southwest bringing clouds and rain. $\mathrm{NO}_{2}$ was present at concentrations of typically between 1 and $2 \mathrm{ppb}$ at night, with excursions up to $4 \mathrm{ppb}$. Daytime mixing ratios were generally less than $10 \mathrm{ppb} . \mathrm{O}_{3}$ was present at levels between 30 and $75 \mathrm{ppb}$, with maximum mixing ratios of $\sim 55-75 \mathrm{ppb}$ encountered in the late afternoon, which usually decreased steadily (by 10-20 ppb) during the night. The HLUG $\mathrm{O}_{3}$ mixing ratios have been multiplied by a factor 0.82 to bring them into line with the MPI measurements, which are considered to be more reliable due to frequent calibration.

The high levels of night-time $\mathrm{O}_{3}$ ensured that NO levels were low and usually close to the instrumental detection limit. The conditions were therefore conducive for $\mathrm{NO}_{3}$ chemistry (sufficient $\mathrm{NO}_{\mathrm{x}}$ and $\mathrm{O}_{3}$ to drive formation and no NO) and both $\mathrm{NO}_{3}$ and $\mathrm{N}_{2} \mathrm{O}_{5}$ were detected on all nights in which the instrument was operated, with maximum mixing ratios of $\sim 500 \mathrm{ppt}$ and $60 \mathrm{ppt}$ observed for $\mathrm{N}_{2} \mathrm{O}_{5}$ and $\mathrm{NO}_{3}$, respectively. A more detailed view is given in Fig. 4, which displays data from one night only (12-13 May). On this night, $\mathrm{NO}_{3}$ and $\mathrm{N}_{2} \mathrm{O}_{5}$ mixing ratios increased above the detection limit shortly after local sunset (at $\sim 21: 00$ ) when both photolysis and NO levels were sufficiently reduced. The lifetime of $\mathrm{NO}$ in the presence of $\sim 60 \mathrm{ppb}$ of $\mathrm{O}_{3}$ is only about $1 \mathrm{~min}$, so that the slow decrease in NO after 19:00 simply reflects the decrease in light intensity and the decreasing photolysis rate of $\mathrm{NO}_{2}$. Maximum values of $\sim 25$ and 70 ppt were reached by $\mathrm{NO}_{3}$ and $\mathrm{N}_{2} \mathrm{O}_{5}$, respectively, both displaying great temporal variability, with fluctuations of $15-20 \mathrm{ppt}$ (i.e. up to $50 \%$ signal modulation) in one minute (see Fig. S1 of the supplementary information (http://www.atmos-chem-phys.net/10/2795/2010/ acp-10-2795-2010-supplement.pdf) for an example). The short term variability (minutes) of $\mathrm{NO}_{3}$ and $\mathrm{N}_{2} \mathrm{O}_{5}$ is typical of a ground site (Brown et al., 2003b). A major contributor to the variability is expected to be sampling of air masses that originate from different altitudes and which have experienced variable rates of loss to both gas-phase reactions and reactions with surfaces including vegetation and architecture between the emission region and the measurement site.

On a slightly longer time scale $(10-15 \mathrm{~min})$ there is evidence for variability driven by fluctuations in the $\mathrm{NO}_{2}$ mixing ratio (e.g. between $\sim 3$ a.m. and 5 a.m. on the 13th) which, together with $\mathrm{O}_{3}$, defines the production rate of $\mathrm{NO}_{3}$ and $\mathrm{N}_{2} \mathrm{O}_{5}$. At sunrise $\left(\sim 05: 30\right.$ local time) both $\mathrm{NO}_{3}$ and $\mathrm{N}_{2} \mathrm{O}_{5}$ are rapidly depleted as $J_{\mathrm{NO} 3}$ increases. The direct photolysis of $\mathrm{NO}_{3}$ depletes $\mathrm{N}_{2} \mathrm{O}_{5}$ via the equilibrium (R2a, $\mathrm{R} 2 \mathrm{~b}$ ) and also releases $\mathrm{NO}$ to further remove $\mathrm{NO}_{3}$. $\mathrm{NO}$ is also generated in the photolysis of $\mathrm{NO}_{2}$ at roughly the same time, and both $\mathrm{NO}_{3}$ and $\mathrm{N}_{2} \mathrm{O}_{5}$ return to below detection limit within $1 \mathrm{~h}$. During this period, $\mathrm{NO}_{2}$ and $\mathrm{NO}$ 

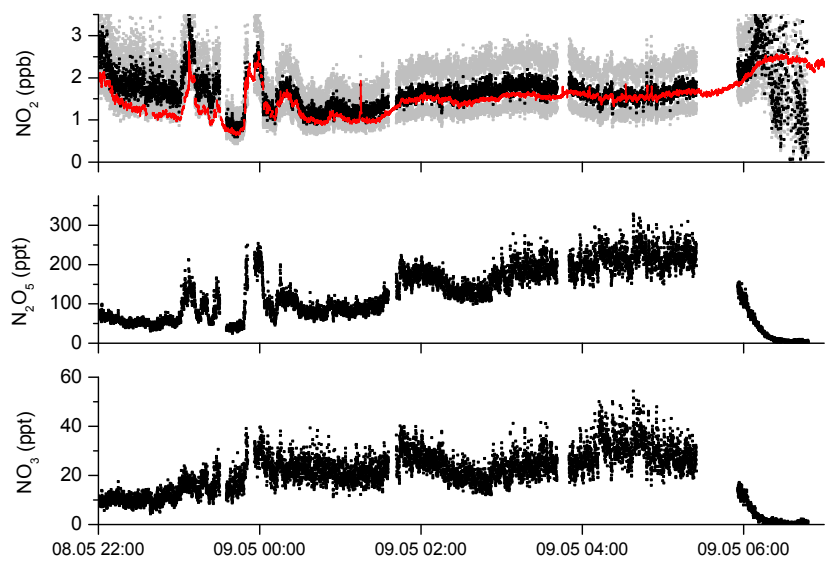

Fig. 5. Measured mixing ratios of $\mathrm{NO}_{2}$, (upper panel, red line) $\mathrm{NO}_{3}$ (lower panel) and $\mathrm{N}_{2} \mathrm{O}_{5}$ (centre). The calculated $\mathrm{NO}_{2}$ mixing ratios (black line in upper panel with grey error bounds) used evaluated, temperature dependent values of $K_{2}$ (Sander et al., 2003).

are observed to increase by $450 \mathrm{ppt}$ and $20 \mathrm{ppt}$, respectively. The amount of $\mathrm{NO}_{2}$ released from the degradation of $\mathrm{NO}_{3}$ and $\mathrm{N}_{2} \mathrm{O}_{5}$ can be estimated as $2 \times\left[\mathrm{N}_{2} \mathrm{O}_{5}\right]+\left[\mathrm{NO}_{3}\right]$, which, for the data in Fig. 4, amounts to $\sim 140$ ppt. This accounts for only $\sim 30 \%$ of the total increase in $\mathrm{NO}_{\mathrm{x}}$ directly after sunrise. The extra $\mathrm{NO}_{\mathrm{x}}$ observed cannot be from degradation of the expected major long lived reservoir species (e.g. $\mathrm{HNO}_{3}$ and PAN). HONO photolysis may however play a role. Assuming $300 \mathrm{ppt}$ HONO at dawn and an approximate, average value of J-HONO $\sim 1 \times 10^{-4} \mathrm{~s}^{-1}$ (Kraus and Hofzumahaus, 1998) over a 40 min period would result in the release of $\sim 70 \mathrm{ppt}$ of NO. A further possibility is upslope winds (caused by warming of the easterly side of the mountain as the sun rose) bringing fresh $\mathrm{NO}_{\mathrm{x}}$ to the site. On one morning (10 May) an excess release of $\mathrm{NO}_{\mathrm{x}}$ was not observed, and the generated amounts of $\mathrm{NO}$ and $\mathrm{NO}_{2}$ agreed with that released from $\mathrm{NO}_{3}$ and $\mathrm{N}_{2} \mathrm{O}_{5}$. As 10 May 2008 was a Saturday, this may indicate a weekend effect, with upslope winds bringing less locally emitted pollution from early morning commuter traffic.

The blue, vertical lines indicate at which times the Teflon filter was changed. Filter changing was conducted manually, and took $\sim 1-2 \mathrm{~min}$. On this night, there was no evidence for loss of $\mathrm{N}_{2} \mathrm{O}_{5}$ or $\mathrm{NO}_{3}$ on the filter, which would have been observable as an increase in the $\mathrm{NO}_{3}$ or $\mathrm{N}_{2} \mathrm{O}_{5}$ signal directly after filter changing.

\subsection{Equilibrium between $\mathrm{NO}_{2}, \mathrm{NO}_{3}$ and $\mathrm{N}_{2} \mathrm{O}_{5}$}

According to Reactions (R2a) and (R2b), the relative concentrations of $\mathrm{NO}_{3}$ and $\mathrm{N}_{2} \mathrm{O}_{5}$ should be controlled by the temperature dependent equilibrium constant $\left(K_{2}\right)$ and the concentration of $\mathrm{NO}_{2}$. The time for a chemical system to relax to equilibrium is the sum of the inverse forward and back rate constants, i.e., with $\mathrm{NO}_{2}$ in large excess over $\mathrm{NO}_{3}$ :

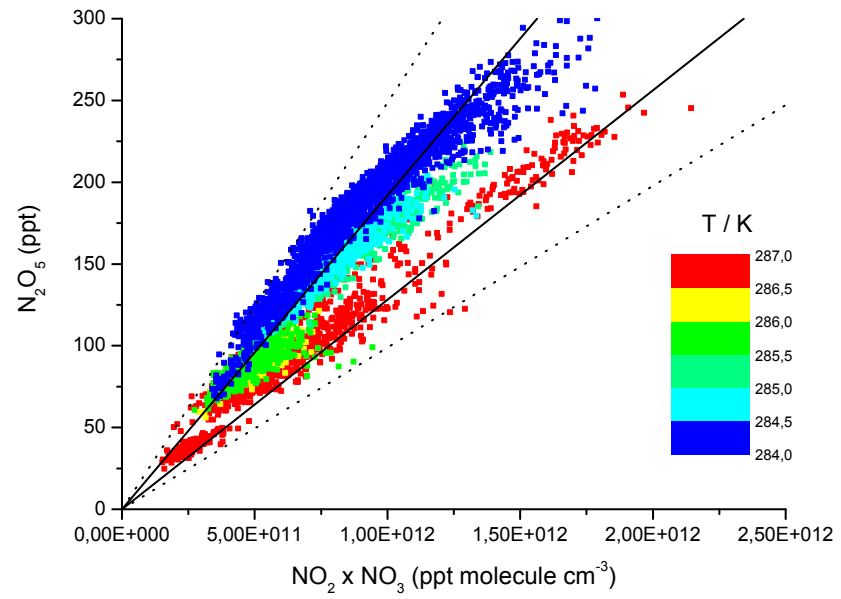

Fig. 6. Determination of the equilibrium constant, $K_{2}$. The $\mathrm{NO}_{2}$, $\mathrm{N}_{2} \mathrm{O}_{5}$ and $\mathrm{NO}_{3}$ data used were gathered over an $\sim 3 \mathrm{~h}$ period $(01: 00$ to 03:00) on 9 May when the $\mathrm{NO}_{3}$ level was above 7 ppt. The solid black lines represent the expected slopes (calculated using literature values for $K_{2}$ ) at the extremes of the small temperature range covered, and should therefore encompass all the data. The dotted black lines use the values of $K_{2}$ at the outer bounds of the recommended uncertainty in this parameter.

$\tau_{\mathrm{eq}}=\frac{1}{k_{2}\left[\mathrm{NO}_{2}\right]+k_{-2}}$

At pressures close to $1 \mathrm{bar}$, the rate constant for the forward reaction $\left(k_{2}\right)$ is circa $10^{-12} \mathrm{~cm}^{3}$ molecule $\mathrm{e}^{-1} \mathrm{~s}^{-1}$, which when combined with typical $\mathrm{NO}_{2}$ concentrations of $1.5 \mathrm{ppb}$ $\left(\sim 4 \times 10^{10}\right.$ molecule $\left.\mathrm{cm}^{-3}\right)$, gives a first-order $\mathrm{N}_{2} \mathrm{O}_{5}$ formation rate constant of $0.04 \mathrm{~s}^{-1}$. The thermal dissociation rate constant for $\mathrm{N}_{2} \mathrm{O}_{5}\left(k_{-2}\right)$ is $0.0064 \mathrm{~s}^{-1}$ at the average nighttime temperature of $11 \pm 1.5^{\circ} \mathrm{C}$. This results in a relaxation time to thermal equilibrium of $\sim 100 \mathrm{~s}$ and implies that, in the absence of very local sources or sinks of $\mathrm{NO}_{3}$ or $\mathrm{N}_{2} \mathrm{O}_{5}$, these species should be in thermal equilibrium. Qualitative confirmation of this could be observed during measurements as even rapid changes in $\mathrm{NO}_{3}$ and $\mathrm{N}_{2} \mathrm{O}_{5}$ (see discussion of variability above) closely tracked each other.

Whether equilibrium was acquired could be tested by making a point-by-point comparison of the measured $\mathrm{NO}_{2}$ mixing ratio (interpolated onto the same time grid as the $\mathrm{NO}_{3} / \mathrm{N}_{2} \mathrm{O}_{5}$ data) with that calculated from the $\mathrm{NO}_{3}$ and $\mathrm{N}_{2} \mathrm{O}_{5}$ observations, the temperature and the literature value for $K_{2}(T)$, which is recommended as $K_{2}=3.0 \times 10^{-27} \exp (10990 / T)$ (Sander et al., 2006). The results are shown for the night 8-9 June in Fig. 5. As data filter, only $\mathrm{NO}_{3}$ mixing ratios greater than $7 \mathrm{ppt}$ were considered. The black data points in the upper panel of Fig. 5 are the calculated $\mathrm{NO}_{2}$ mixing ratios $\left(\mathrm{NO}_{2}\right.$-calc). The grey data points were calculated using the upper and lower bounds of the propagated overall uncertainty in $\mathrm{NO}_{2}$-calc, which arises from uncertainty in the $\mathrm{NO}_{3}$ and $\mathrm{N}_{2} \mathrm{O}_{5}$ mixing ratios and the uncertainty in $K_{2}$ at $285 \mathrm{~K}$ (factor of 1.3). The red line is the CLD measurement of $\mathrm{NO}_{2}$. There is good agreement 
between the measured and calculated $\mathrm{NO}_{2}$ mixing ratios on this night, with the major features in $\mathrm{NO}_{2}$ around midnight, when variations between 0.5 and $3 \mathrm{ppb}$ are nicely captured.

From expression (2), a plot of the product of the $\mathrm{NO}_{2}$ and $\mathrm{NO}_{3}$ mixing ratios versus the $\mathrm{N}_{2} \mathrm{O}_{5}$ mixing ratio should be a straight line with the slope equal to $K_{2}$. Such a plot is shown (Fig. 6) for the same dataset (night 8-9 June, 01:00-03:00, $\mathrm{NO}_{3}>7 \mathrm{ppt}$ ). The measured $\mathrm{NO}_{2}$ mixing ratio was converted to a concentration so that the slope is an equilibrium constant in the usual units of inverse concentration $\left(\mathrm{cm}^{3}\right.$ molecule $\left.{ }^{-1}\right)$. The temperature for each $\mathrm{NO}_{3} / \mathrm{N}_{2} \mathrm{O}_{5} / \mathrm{NO}_{2}$ datapoint varied from $\sim 284$ to $287 \mathrm{~K}$ during the night (see colour scale). Even though the difference between maximum and minimum temperature was only $\sim 3 \mathrm{~K}$, it is apparent that the data points obtained at the coolest temperatures result in the largest slope (largest values of $K_{2}$ ), reflecting the strong temperature dependence in $K_{2}$. The solid black lines represent the expected slopes at the extremes of the small temperature range covered, and should therefore encompass all the data. The dotted black lines use the values of $K_{2}$ at the outer bounds of the recommended uncertainty in this parameter. Essentially all of the data is encompassed by the dotted lines. The relevant temperature for calculating the equilibrium constant is not necessarily that at the inlet, but that experienced by the air mass during the last $\sim 100 \mathrm{~s}$ (approximate relaxation time to equilibrium for the conditions at the Kleiner Feldberg) prior to entering the inlet. As our temperatures are those measured by the German weather service station $\sim 20 \mathrm{~m}$ distant from our inlet this represents a source of uncertainty in our calculations. In this context, the night-time temperatures reported by the local environmental agency (HLUG) are $\sim 0.5^{\circ} \mathrm{C}$ lower than reported by the DWD.

Nonetheless, by selecting data within small temperature windows we were able to derive values of $K_{2}=1.95 \times 10^{-10} \mathrm{~cm}^{3}$ molecule $^{-1}(284>T>283 \mathrm{~K}$, average temperature $284.3 \mathrm{~K}$ ) and $K_{2}=1.44 \times 10^{-10} \mathrm{~cm}^{3}$ at molecule $^{-1}(287>T>286$ average temperature $286.8 \mathrm{~K})$ with a proportional fit to the data. The uncertainty associated with these values of $K_{2}$ derived from the field data are related to uncertainty in the $\mathrm{NO}_{3}, \mathrm{~N}_{2} \mathrm{O}_{5}$ and $\mathrm{NO}_{2}$ measurements, which propagate to a value of $\sim 23 \%$. and, more significantly, are impacted by the unknown temperature history of the air mass directly before sampling (see above). The statistical errors associated with the fit were less than $1 \%$.

The values of $K_{2}$ listed above are in very close agreement (within 2\%) with recent measurements made in the field using simultaneous detection of $\mathrm{NO}_{2}, \mathrm{NO}_{3}$ and $\mathrm{N}_{2} \mathrm{O}_{5}$ (Osthoff et al., 2007). They also agree (within 7\%) with literature evaluations (Sander et al., 2003) of 1.89 and $1.35 \times 10^{-10} \mathrm{~cm}^{3}$ molecule ${ }^{-1}$ at these respective temperatures. We note that a later evaluation by the same panel and using the same database (Sander et al., 2006) results in slightly worse, but, given the uncertainties involved, acceptable, agreement.

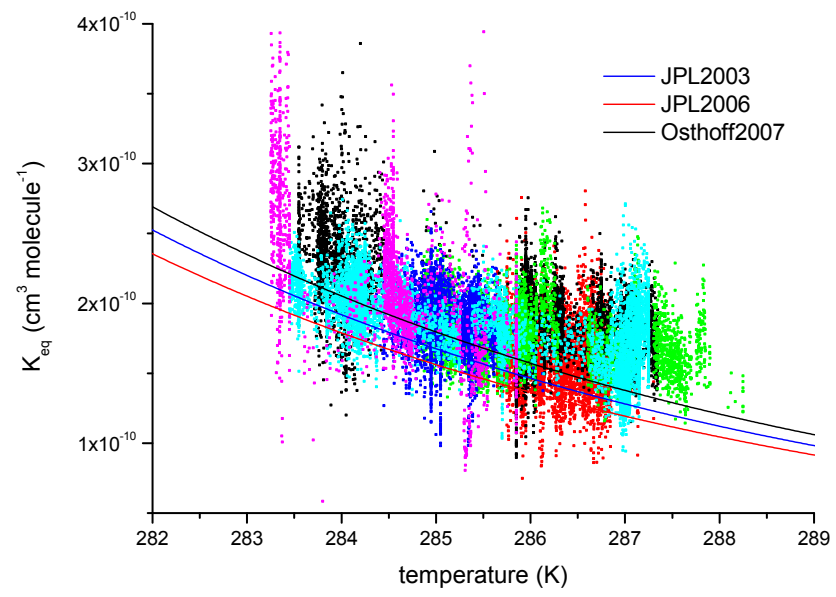

Fig. 7. Determination of the equilibrium constant, $K_{2}$ throughout the campaign plotted versus temperature. Data were selected so that $\mathrm{NO}_{3}$ was always greater than $5 \mathrm{ppt}$. The red and blue solid lines are recommended values for $K_{2}$ from evaluations of laboratory data. The black line is taken from the analysis of Osthoff et al. (2007), based on their field measurements. Different colours are data from different days. JPL2003 = Sander et al. (2003), JPL2006 = Sander et al. (2006), Osthoff2007 = Osthoff et al. (2007).

In Fig. 7, we present equilibrium constants calculated from measured mixing ratios of $\mathrm{NO}_{2}, \mathrm{NO}_{3}$ and $\mathrm{N}_{2} \mathrm{O}_{5}$ for each night of the campaign. To avoid systematic error at low mixing ratios, data were selected so that the $\mathrm{NO}_{3}$ mixing ratio was always greater than 5 ppt.

The temperature dependent values of $K_{2}$ thus calculated are compared with evaluations (JPL, 2003, 2006) and recent field determinations (Osthoff et al., 2007). Despite significant scatter in the data is it apparent that, even when neglecting the $30 \%$ overall error in our measurements of $\mathrm{NO}_{3}$ and $\mathrm{N}_{2} \mathrm{O}_{5}$, the calculated values of $K_{2}$ are consistent with the recommended values, with slightly better agreement with the field data of Osthoff et al. (2007).

To date, there have been only a few simultaneous measurements of $\mathrm{NO}_{2}, \mathrm{NO}_{3}$ and $\mathrm{N}_{2} \mathrm{O}_{5}$. Our data at the Kleiner Feldberg support observations (Brown et al., 2003b; Aldener et al., 2006; Osthoff et al., 2007) that thermal equilibrium exists at night between these three trace gases under most conditions, the possible exception being at low temperatures. Our data may also be considered to provide confirmation of the laboratory derived equilibrium constant $K_{2}$, which has usually been obtained by measuring individual rate constants for the forward and backward processes (Reactions R2a and $\mathrm{R} 2 \mathrm{~b}$ ) via pseudo first-order analysis rather than measurement of equilibrium concentrations, which is difficult to achieve in laboratory set-ups with reactive surfaces. The notable exception to this being the work of Osthoff et al. (2007), in a well characterised, multi-channel cavity apparatus, whose laboratory derived equilibrium constants agree very well with ours (within 6\%). 
Conversely, assuming that the laboratory derived equilibrium constant is accurately known, we can conclude that our two-channel set-up for $\mathrm{NO}_{3}$ and $\mathrm{N}_{2} \mathrm{O}_{5}$ (used for the first time in this campaign) and the associated data correction procedure can accurately measure ambient $\mathrm{NO}_{3}$ and $\mathrm{N}_{2} \mathrm{O}_{5}$ mixing ratios. Poor agreement between calculated $\mathrm{NO}_{2}$ concentrations (via $\mathrm{NO}_{3}, \mathrm{~N}_{2} \mathrm{O}_{5}$ and $K_{2}$ ) and those measured directly were however occasionally observed. This occurred when $\mathrm{NO}_{3}$ was reactively lost at an aged Teflon filter, resulting in falsification of the $\mathrm{N}_{2} \mathrm{O}_{5} / \mathrm{NO}_{3}$ ratio and subsequent overestimation of the $\mathrm{NO}_{2}$ concentration. Although small, post filter-change discontinuities in the $\mathrm{NO}_{3}$ signals were usually concealed by their large variability, they were clearly evident in the calculated $\mathrm{NO}_{2}$ mixing ratio as short term variability in $\mathrm{NO}_{3}$ and $\mathrm{N}_{2} \mathrm{O}_{5}$ were closely matched and thus cancelled. Evidence for $\mathrm{NO}_{3}$ filter loss was seen in the dataset from the 9th-10th when filter changes were performed only every two hours. Similarly, on one night (13-14 May) the high-volume flow inlet was replaced by a $3 / 8^{\prime \prime}$ PFA tube of $\sim 550 \mathrm{~cm}$ length. This resulted in a $\sim 30 \%$ increase in the calculated, equilibrium amount of $\mathrm{NO}_{2}$ over a period when $\mathrm{NO}_{2}$ was actually stable, indicating that $\sim 30 \%$ of the $\mathrm{NO}_{3}$ had been lost in the inlet. Note that the residence time in the $550 \mathrm{~cm}$ length of tubing was $\sim 0.9 \mathrm{~s}$. Loss of $\sim 30 \%$ of the $\mathrm{NO}_{3}$ is thus broadly consistent with the loss rate coefficient of $0.25 \mathrm{~s}^{-1}$ in PFA tubing reported in the experimental section.

\section{2 $\mathrm{NO}_{3}$ and $\mathrm{N}_{2} \mathrm{O}_{5}$ lifetimes and loss rates}

The $\mathrm{NO}_{3}$ turnover lifetime (see Eq. 3) at the Taunus Observatory was highly variable with maximum values of $\sim 1500 \mathrm{~s}$. Generally, the $\mathrm{NO}_{3}$ lifetime was longest after $\sim$ 03:00 following a slow increase from dusk. This is most apparent (Fig. 8) on the nights of the 9th, 12th and 13th, in which the lifetime directly after dusk (at $\sim 20: 00$ ) remained under $\sim 200$ s for the next $\sim 3 \mathrm{~h}$. Figure 8 also shows the instantaneous $\mathrm{NO}_{3}$ production $\left(k_{1}\left[\mathrm{NO}_{2}\right]\left[\mathrm{O}_{3}\right]\right)$ rates during each night (red lines), which were typically between 100 and $300 \mathrm{ppt} / \mathrm{h}$ and fairly constant but with some excursions to larger values due to influxes of $\mathrm{NO}_{2}$.

Recall that the $\mathrm{NO}_{3}$ lifetime is determined by both direct losses (e.g. gas- phase reaction with biogenic organics) and indirect loss processes involving $\mathrm{N}_{2} \mathrm{O}_{5}$. The slow increase in $\mathrm{NO}_{3}$ lifetime after dusk may thus have been due to either a decrease in gas-phase reactivity after dusk or due to a decrease in surface area or reactivity of aerosol. As the NO levels were reduced to below the detection limit in just a few minutes after dusk, the slow rate of build up of $\mathrm{NO}_{3}$ and $\mathrm{N}_{2} \mathrm{O}_{5}$ was not due to a reduction in its concentration during this period. Alternatively, an increase in lifetime could also be related to a stabilisation of the lower atmosphere by adiabatic cooling, which would reduce turbulence and thus dry deposition rates. However, the observation on most nights of the campaign of a clear increase in wind speed following sunset, does not support this possibility.

Before examining aspects of the $\mathrm{NO}_{3}$ lifetime in more detail it is worthwhile establishing whether a stationary state analysis was applicable for this dataset. Stationary state is formally achieved when the rate of change of $\mathrm{NO}_{3}$ and $\mathrm{N}_{2} \mathrm{O}_{5}$ are zero, i.e. $d \mathrm{NO}_{3} / d t=k_{1}\left[\mathrm{NO}_{2}\right]\left[\mathrm{O}_{3}\right]+k_{-2}\left[\mathrm{~N}_{2} \mathrm{O}_{5}\right]-k_{2}\left[\mathrm{NO}_{2}\right]\left[\mathrm{O}_{3}\right]-f_{\text {dir }}$ $\left(\mathrm{NO}_{3}\right)\left[\mathrm{NO}_{3}\right]=0$ and $d \mathrm{~N}_{2} \mathrm{O}_{5} / d t=k_{2}\left[\mathrm{NO}_{2}\right]\left[\mathrm{NO}_{3}\right]-k_{-2}\left[\mathrm{~N}_{2} \mathrm{O}_{5}\right]$ $-\left(f_{\text {het }}+f_{\text {homo }}\right)\left[\mathrm{N}_{2} \mathrm{O}_{5}\right]=0$. The approximate time to acquire stationary state thus depends on the production and loss rates of both $\mathrm{NO}_{3}$ and $\mathrm{N}_{2} \mathrm{O}_{5}$.

Time dependent values of $d \mathrm{NO}_{3} / d t$ and $d \mathrm{~N}_{2} \mathrm{O}_{5} / d t$ were determined by numerical simulation in a manner similar to that described by Brown et al. (2003a). Input parameters to the simulations were the measured $\mathrm{NO}_{2}$ and $\mathrm{O}_{3}$ concentrations and temperature dependent kinetic expressions for Reactions (R1), (R2) (together defining the production rates of $\mathrm{NO}_{3}$ and $\mathrm{N}_{2} \mathrm{O}_{5}$ ) and variable first order loss terms for removal of $\mathrm{NO}_{3}$ and $\mathrm{N}_{2} \mathrm{O}_{5}$. The first-order loss terms for $\mathrm{NO}_{3}$ and $\mathrm{N}_{2} \mathrm{O}_{5}\left(f_{\text {dir }}\left(\mathrm{NO}_{3}\right), f_{\text {het }}, f_{\text {homo }}\right)$ were adjusted until the simulated $\mathrm{NO}_{3}$ and $\mathrm{N}_{2} \mathrm{O}_{5}$ mixing ratios were similar to those measured. In conjunction with $\mathrm{NO}_{3}$ and $\mathrm{N}_{2} \mathrm{O}_{5}$ lifetimes of the order of minutes, the relatively warm night-time temperatures and low $\mathrm{NO}_{2}$ concentrations at the Kleiner Feldberg in May, meant that stationary state was achieved within 1$2 \mathrm{~h}$ after dusk. Given the distance to local emission regions (see above) and wind speeds of between 10 and $20 \mathrm{~km} / \mathrm{h}$ this suggest that a steady state analysis was appropriate.

The slow increase in $\mathrm{NO}_{3}$ lifetime early in the night could have been caused by a reduction in the mixing ratio of biogenic trace gases in the hours following dusk. Using rate coefficients of $7.0 \times 10^{-13}$ and $6.2 \times 10^{-12} \mathrm{~cm}^{3}$ molecule ${ }^{-1} \mathrm{~s}^{-1}$ for reaction of $\mathrm{NO}_{3}$ with isoprene and $\alpha$-pinene, respectively (IUPAC, 2009) and initially ignoring indirect loss processes, we calculate that a $\mathrm{NO}_{3}$ lifetime of $\sim 100 \mathrm{~s}$ would be associated with isoprene levels of $0.60 \mathrm{ppb}$ or $\alpha$-pinene levels of $\sim 68$ ppt. Emissions of biogenic organics are temperature and light-intensity dependent (Fehsenfeld et al., 1992) and the levels mentioned above would appear reasonable for moderate, spring-time emissions of biogenic organics in a forested area.

As we did not take measurements of organic compounds during the campaign we have no data which confirm efficient removal of $\mathrm{NO}_{3}$ by e.g. isoprene or $\alpha$-pinene. There appear to be no published datasets on measurements of gas-phase biogenic trace gases at the Kleiner Feldberg, though some data taken with a proton transfer mass spectrometer over a 4 day period in June of 2005 confirmed the expected presence of isoprene and terpenes in this forested area (V. Sinha and J. Williams, personal communication, 2009). Furthermore, these datasets indicate that both isoprene and terpene concentrations decreased slowly after sundown, only returning to baseline levels in the early hours of the next morning. 

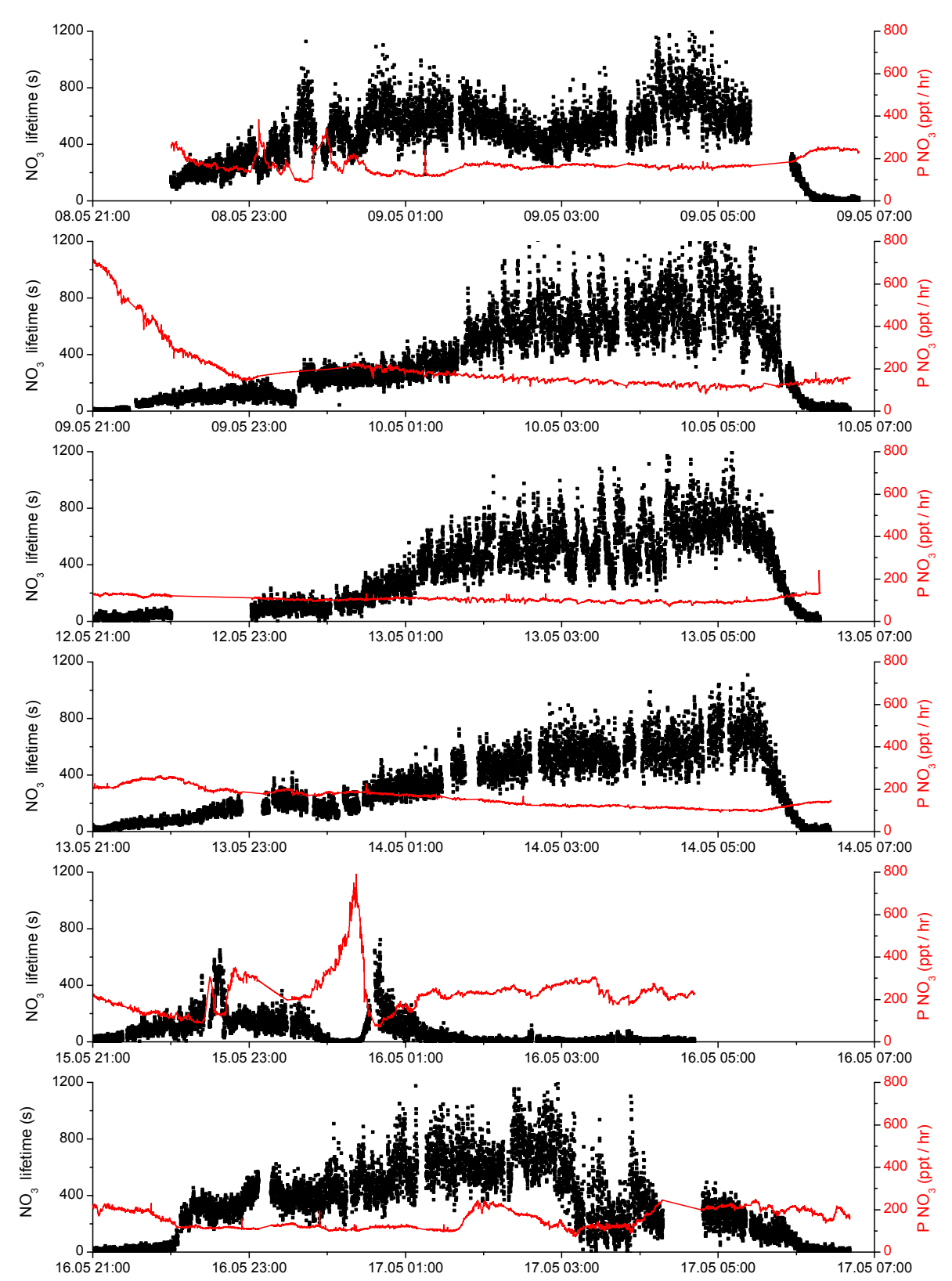

Fig. 8. $\mathrm{NO}_{3}$ turn-over lifetimes and production rates (red lines) on each night of the campaign.

This observation is thus consistent with the observed slow increase in $\mathrm{NO}_{3}$ lifetimes over the same period.

A further indication for the presence of biogenic volatile organic compounds (VOCs) is the observation of new particle formation at the Kleiner Feldberg; indeed April-May was the most intense nucleation period during 2008. New particle formation took place during the measurement period on the following days: $8-13$ and 15 May (day-time events) as well as during the evening of the 7 and 14 May (night-time events). Temperatures were moderately high and the nocturnal boundary layer rather shallow to facilitate accumulation of emitted VOCs. From the 15th onward the relative humidity increased substantially causing drizzle or rain and prevented the occurrence of nucleation. During this time the vegetation experienced reduced drought stress resulting (presumably) in lower emission rates. At the same time aerosol mass and surface area declined because of wash out from the atmosphere. In the absence of simultaneous measurements of biogenics or other reactive traces gases (e.g. unsaturated hydrocarbons) that could react with $\mathrm{NO}_{3}$, the above discussion about the main $\mathrm{NO}_{3}$ loss reactions remains speculative.

On the last two days of the campaign, the $\mathrm{NO}_{3}$ lifetime did not show a slow increase to a maximum value, but had already reached $\sim 300-400 \mathrm{~s}$ by $23: 00 \mathrm{~h}$ (Fig. 8 ). As shown in 
Fig. 3, the last two days were meteorologically distinct from the first 4 as the wind direction changed to southwest, bringing cloud cover, lower temperatures and later in the night, rain and fog. The longer lifetime of $\mathrm{NO}_{3}$ early on these nights was presumably related to reduced biogenic emissions. The periodic strong reductions in lifetime on the night 15-16 May was coincident with precipitation at the site, presumably resulting in loss of $\mathrm{N}_{2} \mathrm{O}_{5}$ on large droplets (not monitored as the aerosol cut off was $\sim 0.5 \mu \mathrm{m}$ ) or deposition to moist surfaces. Further, indirect processes leading to a reduction in the $\mathrm{NO}_{3}$ lifetime are the loss of $\mathrm{N}_{2} \mathrm{O}_{5}$ on aerosol surface and with $\mathrm{H}_{2} \mathrm{O}$ vapour. By inverting expression (3) we obtain:

$$
f_{\mathrm{ss}}\left(\mathrm{NO}_{3}\right) \approx f_{\text {dir }}+K_{\mathrm{eq}}\left[\mathrm{NO}_{2}\right]\left(f_{\text {het }}+f_{\text {homo }}\right)
$$

The relative importance of direct (gas-phase) and indirect (gas-phase and heterogeneous) losses of $\mathrm{NO}_{3}$ are displayed for the nights of 13 and 16 May in Fig. 9. The heterogeneous loss rate of $\mathrm{N}_{2} \mathrm{O}_{5}\left(f_{\text {het }}\right)$ was calculated from the measured aerosol surface area using expression (4) and scaled by $K_{2}\left[\mathrm{NO}_{2}\right]$ and is presented in Fig. 9 (blue line). The value used for the uptake coefficient, $\gamma$, was 0.01 , which is within the very large range of values derived from field observations. For example, low values of $0.5-6 \times 10^{-3}$ have been reported by Brown et al. (2009) in aircraft measurements over Texas, which are consistent with $\sim 3 \times 10^{-3}$ reported by Allan et al. (1999); Ambrose et al. (2007) in marine air masses but much lower than values of 0.02-0.03 (Aldener et al., 2006; Ambrose et al., 2007) also obtained in marine environments. The uptake coefficient used is also smaller by a factor $\sim 3$ than measured for loss of $\mathrm{N}_{2} \mathrm{O}_{5}$ to dilute $\mathrm{H}_{2} \mathrm{SO}_{4}$ aerosol in the laboratory (Hallquist et al., 2000), though further laboratory studies have shown that the presence of organics can reduce this number significantly (Folkers et al., 2003). Although no aerosol composition data is available, some indication for the type of aerosol encountered at the Taunus Observatory was obtained by observing loss of $\mathrm{NO}_{3}$ on an aged Teflon filter. In this case, an increase in $\mathrm{NO}_{3}$ mixing ratio was seen directly after a filter change but was not accompanied by an increase in $\mathrm{N}_{2} \mathrm{O}_{5}$. This implies that the aerosol gathered on the filter contained a large organic fraction providing a reactive surface for $\mathrm{NO}_{3}$ but one that did not support efficient hydrolysis of $\mathrm{N}_{2} \mathrm{O}_{5}$. On the 13 May, it is clear from Fig. 9 that heterogeneous loss of $\mathrm{N}_{2} \mathrm{O}_{5}$ would have contributed only insignificantly to $\mathrm{NO}_{3}$ removal even if $\gamma=0.03$ had been used in the calculation. A similar picture emerges for the other nights before the 15th when the wind direction was predominantly Easterly and daytime temperatures were highest. In this period, the calculated maximum $\mathrm{NO}_{3}$ loss rates due to heterogeneous loss of $\mathrm{N}_{2} \mathrm{O}_{5}$ were between 1.5 and $6 \times 10^{-4} \mathrm{~s}^{-1}$ at the end of the night when the $\mathrm{NO}_{3}$ lifetime was longest. Even then, the heterogeneous loss of $\mathrm{N}_{2} \mathrm{O}_{5}$ contributed between only 7 and $28 \%$. When averaged over the whole night, this number becomes insignificantly small.

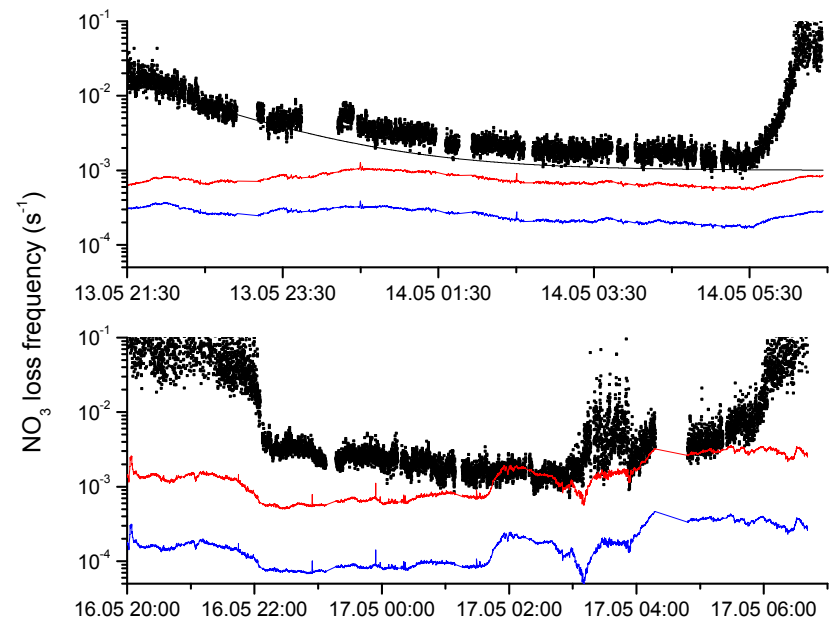

Fig. 9. Measured $\mathrm{NO}_{3}$ turnover loss frequencies (black datapoints) and calculated loss frequencies due to direct and indirect loss processes on two different nights. Grey line (upper panel only): Hypothetical (direct) loss of $\mathrm{NO}_{3}$ due to reaction with VOC. Blue line: Indirect loss due to $\mathrm{N}_{2} \mathrm{O}_{5}$ uptake to aerosol $\left(f_{\text {het }} K_{2}\left[\mathrm{NO}_{2}\right]\right)$. Red line: Indirect loss due to reaction of $\mathrm{N}_{2} \mathrm{O}_{5}$ with water vapour $\left(f_{\text {homo }} K_{2}\left[\mathrm{NO}_{2}\right]\right)$.

The frequency of $\mathrm{NO}_{3}$ loss from stationary state caused by the homogeneous reaction of $\mathrm{N}_{2} \mathrm{O}_{5}$ with water vapour ( $\left.f_{\text {homo }} K_{2}\left[\mathrm{NO}_{2}\right]\right)$ was initially calculated using the rate coefficients $\left(k_{7 \mathrm{a}}\right.$ and $k_{7 \mathrm{~b}}$ ) preferred by IUPAC (Atkinson et al., 2004), with $\mathrm{H}_{2} \mathrm{O}$ vapour concentrations calculated from the $\mathrm{RH}$ and temperature/pressure measurements of the DWD. The loss of $\mathrm{NO}_{3}$ via this indirect route contributes to its overall loss only later in the night when the overall reactivity of the air has decreased.

Note that the indirect losses of $\mathrm{NO}_{3}$ via homogeneous and heterogeneous $\mathrm{N}_{2} \mathrm{O}_{5}$ reactions are constrained by measurements of $\mathrm{H}_{2} \mathrm{O}$ vapour and aerosol surface area which do not show a significant trend during the night. Unless the aerosol composition changes greatly during the night (being initially much more reactive than defined by the uptake coefficient above and subsequently becoming increasingly less reactive towards $\mathrm{N}_{2} \mathrm{O}_{5}$ ), indirect losses are unlikely to have caused the reduction in reactivity (factor of 10) observed after dusk. In order to reproduce the time dependence of the $\mathrm{NO}_{3}$ turnover lifetime on the night $12-13$ May, $f_{\text {dir }}\left(\mathrm{NO}_{3}\right)$ was calculated for an initial total reactivity (at dusk) equal to about 200 ppt $\alpha$-pinene equivalents, which was reduced during the night to $\sim 10 \mathrm{ppt}$ (at 03:00) in a quasi-exponential manner, thus increasing the lifetime from $\sim 50 \mathrm{~s}$ at $21: 00$ on 13 May to $\sim 1000 \mathrm{~s}$ at 03:00 the next morning (grey line, Fig. 9).

For the night 16-17 May a slightly different picture emerges. On this night the $\mathrm{NO}_{3}$ turn-over lifetime was longer, a result of a decrease in the concentration of VOC and aerosol surface area following a rainy period. Under these 
conditions and with an increase in $\mathrm{RH}$ to close to $100 \%$ the reaction of $\mathrm{N}_{2} \mathrm{O}_{5}$ with $\mathrm{H}_{2} \mathrm{O}$ gains importance and, at 02:00 on the 17th would account for the entire reactivity of the $\mathrm{NO}_{3} / \mathrm{N}_{2} \mathrm{O}_{5}$ system, i.e. $f_{\text {homo }} K_{2}\left[\mathrm{NO}_{2}\right] \sim\left(\tau \mathrm{ss}\left(\mathrm{NO}_{3}\right)\right)^{-1}$ if the IUPAC values were used.

The $\mathrm{NO}_{3}$ losses can be separated into direct and indirect routes by using the fact that the $\mathrm{NO}_{3}$ turnover lifetime depends non-linearly on the $\mathrm{NO}_{2}$ concentration if $\mathrm{N}_{2} \mathrm{O}_{5}$ losses are significant. This is apparent from expression (3), which has been utilised previously to extract e.g. the $\mathrm{N}_{2} \mathrm{O}_{5}$ hydrolysis contribution to $\mathrm{NO}_{3}$ loss (Heintz et al., 1996; Geyer et al., 2001; Aldener et al., 2006; Brown et al., 2006, 2009). Plotting the inverse of the $\mathrm{NO}_{3}$ life-time versus $K_{2}\left[\mathrm{NO}_{2}\right]$ (with $\left[\mathrm{NO}_{2}\right]$ in units of molecule $\mathrm{cm}^{-3}$ ) should give a straight line with slope equal to the $\mathrm{N}_{2} \mathrm{O}_{5}$ loss rate constant, $f_{\text {indir }}\left(\mathrm{NO}_{3}\right)$ and intercept equal to the $\mathrm{NO}_{3}$ loss rate constant $f_{\text {dir }}\left(\mathrm{NO}_{3}\right)$. This analysis requires selection of data in which $f_{\text {dir }}\left(\mathrm{NO}_{3}\right)$ and $f_{\text {indir }}\left(\mathrm{NO}_{3}\right)$ are relatively constant, but for which there is sufficient variation in $\mathrm{NO}_{2}$ to separate the direct and indirect $\mathrm{NO}_{3}$ loss terms. On most nights this analysis resulted in strongly curved plots due to the slowly changing lifetime of $\mathrm{NO}_{3}$ due to reaction with biogenic organics (see above). By selection of a small portion of the data (01:00 to 03:00) on the night of the 16-17 May in which significant variation on $\mathrm{NO}_{2}$ was observed, a linear relationship was obtained (Fig. 10) with a slope $\left(f_{\text {indir }}\left(\mathrm{NO}_{3}\right)\right)$ very close to zero $\left(5 \pm 5 \times 10^{-6} \mathrm{~s}^{-1}\right)$ and intercept of $f_{\text {dir }}\left(\mathrm{NO}_{3}\right)=1.6 \times 10^{-3} \mathrm{~s}^{-1}$ (red line). Setting $\mathrm{N}_{2} \mathrm{O}_{5}$ loss to aerosol to zero $\left(f_{\text {het }}=0\right)$, we take the literature data for $k_{7 \mathrm{a}}$ and $k_{7 \mathrm{~b}}$ and the water vapour concentration of $2.8 \times 10^{17}$ molecule $\mathrm{cm}^{-3}$ to calculate a value of $f_{\text {homo }}=2 \times 10^{-4} \mathrm{~s}^{-1}$ for this period. As shown in Fig. 10 (black line), this value clearly overestimates the true contribution of indirect losses by at least a factor of 34. Reaction (R7b) dominated the homogeneous gas-phase loss of $\mathrm{N}_{2} \mathrm{O}_{5}$ during the whole campaign with the ratio $k_{7 \mathrm{~b}}\left[\mathrm{H}_{2} \mathrm{O}\right]^{2} / k_{7 \mathrm{a}}\left[\mathrm{H}_{2} \mathrm{O}\right]$ as large as $\sim 2.5$ at $\mathrm{RH}=100 \%$. Reaction (R7a) is more important only when $\mathrm{RH}$ was less than $\sim 30 \%$.

This analysis has thus far ignored loss of $\mathrm{N}_{2} \mathrm{O}_{5}\left(\right.$ or $\left.\mathrm{NO}_{3}\right)$ by dry deposition. Aldener et al. (2006) used a $\mathrm{N}_{2} \mathrm{O}_{5}$ deposition velocity $\left(V_{\mathrm{dep}}\right)$ of $1 \mathrm{~cm} \mathrm{~s}^{-1}$ to calculate the contribution of dry deposition to the total loss of $\mathrm{N}_{2} \mathrm{O}_{5}$. This value was based on estimates for $\mathrm{HNO}_{3}$ and is not necessarily accurate. Adopting the same value and assuming a boundary layer height of $100 \mathrm{~m}$ would result in a frequency for dry deposition of $\mathrm{N}_{2} \mathrm{O}_{5}$ of $1 \times 10^{-4} \mathrm{~s}^{-1}$, which when multiplied by $k_{2}\left[\mathrm{NO}_{2}\right]$ (usually close to 10 ) would result in a significant fraction of $\mathrm{NO}_{3}$ loss throughout the campaign. There are however many uncertainties associated with this calculation as neither the true value of $V_{\text {dep }}$ nor the boundary layer height are known. In addition this calculation ignores the strong vertical stratification often seen in the nocturnal boundary layer (Brown et al., 2007). The true factor by which $k_{7}$ is overestimated is thus most probably larger than $3-4$ as $\mathrm{N}_{2} \mathrm{O}_{5}$ loss by dry deposition would serve to increase it further. One

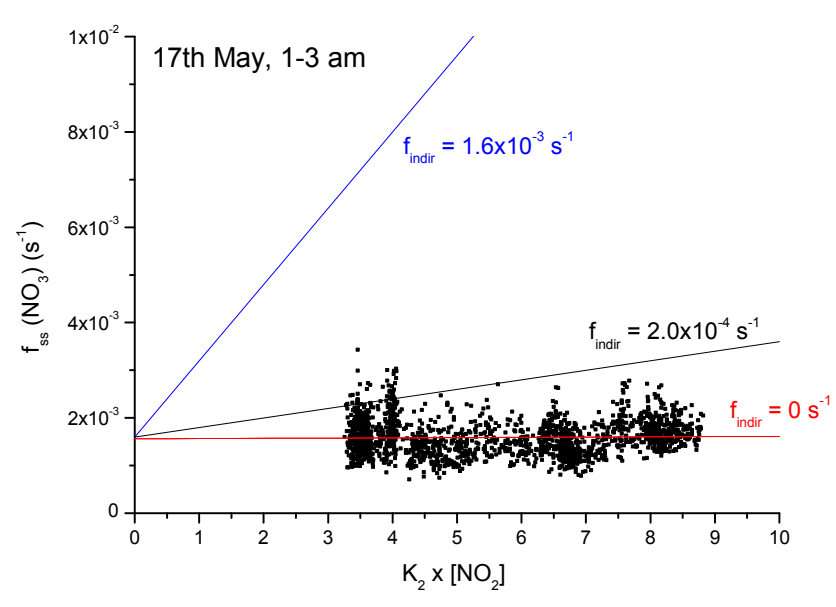

Fig. 10. Separation of direct and indirect loss of $\mathrm{NO}_{3}$ on the night 16-17 May. The red solid line is the fitted value indicating close to zero indirect loss of $\mathrm{NO}_{3}$. The black line was obtained by setting heterogeneous $\mathrm{N}_{2} \mathrm{O}_{5}$ loss to zero and accounting only for reaction with water vapour. The blue line represents equivalency of the direct and indirect losses of $\mathrm{NO}_{3}$ (intercept $=$ slope $=1.6 \times 10^{-3} \mathrm{~s}^{-1}$ ). The difference in slope between this and the red line serves to indicate the dominance of direct loss over indirect loss.

caveat to this approach is, however, the assumption that there is no correlation between $\mathrm{NO}_{2}$ mixing ratios and the major sink process(es) for $\mathrm{NO}_{3}$ and $\mathrm{N}_{2} \mathrm{O}_{5}$, which is difficult to prove. The result is however consistent with the conclusions of Brown et al. (2006, 2009), who used airborne measurements of $\mathrm{NO}_{3}$ and $\mathrm{N}_{2} \mathrm{O}_{5}$ to indicate that $k_{7}$ may be up to a factor 10 smaller than derived from laboratory data.

The blue line in Fig. 10 is the slope expected for equivalent direct and indirect losses of $\mathrm{NO}_{3}$ and indicates that, for this limited dataset, $\mathrm{N}_{2} \mathrm{O}_{5}$ destruction plays only a minor role in controlling the $\mathrm{NO}_{3}$ lifetime. This conclusion is broadly consistent with other measurements at continental, forested sites in Germany, where $\mathrm{NO}_{3}$ has been found to be removed mainly by reaction with monoterpenes emitted by coniferous trees (Geyer and Platt, 2002).

\section{3 $\mathrm{NO}_{\mathrm{x}}$ partitioning and daytime versus night-time loss of $\mathrm{NO}_{\mathrm{x}}$}

The conversion of $\mathrm{NO}_{2}$ to $\mathrm{NO}_{3}$ and $\mathrm{N}_{2} \mathrm{O}_{5}$ followed by reactive losses either with gas-phase species or with aerosols and other surfaces represents a conversion of gas-phase $\mathrm{NO}_{\mathrm{x}}$ trace gases to $\mathrm{NO} z$ in both gas and particle phases. In the absence of $\mathrm{NO}$, the fraction of nitrogen oxides $(F)$, which is present in reactive form (i.e. as $\mathrm{NO}_{3}$ or $\mathrm{N}_{2} \mathrm{O}_{5}$ ) at night can be simply expressed as:

$$
F=\frac{\left[\mathrm{NO}_{3}\right]+2\left[\mathrm{~N}_{2} \mathrm{O}_{5}\right]}{\left[\mathrm{NO}_{3}\right]+2\left[\mathrm{~N}_{2} \mathrm{O}_{5}\right]+\left[\mathrm{NO}_{2}\right]}
$$

This expression ignores longer lived $\mathrm{NO}_{\mathrm{x}}$ reservoir species such as $\mathrm{HNO}_{3}$, PAN or halogenated nitrogen oxides, which, 

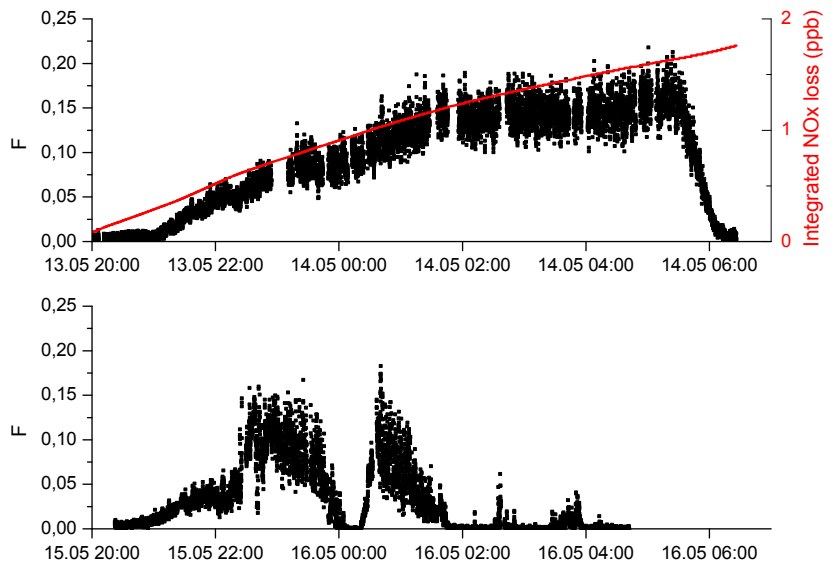

Fig. 11. Fraction $(F)$ of night-time $\mathrm{NO}_{\mathrm{x}}$ as $\mathrm{NO}_{3}$ and $\mathrm{N}_{2} \mathrm{O}_{5}$ on two meteorologically distinct campaign nights. 13th-14th: warm preceding day and wind from the east. 15th-16th: Wind from the southeast accompanied by rain. The solid red line is the integrated $\mathrm{NO}_{\mathrm{x}}$ loss during the night 13-14 May.

unlike $\mathrm{NO}_{3}$ and $\mathrm{N}_{2} \mathrm{O}_{5}$ are not in rapid equilibrium with $\mathrm{NO}_{2}$. The contribution of $\mathrm{NO}_{3}$ and $\mathrm{N}_{2} \mathrm{O}_{5}$ to $\mathrm{NO}_{\mathrm{y}}$ (which would include trace gases such as $\mathrm{HNO}_{3}$ and PAN) is, of course smaller.

The partitioning of $\mathrm{NO}_{\mathrm{x}}$ to $\mathrm{NO}_{3}$ and $\mathrm{N}_{2} \mathrm{O}_{5}$ is favoured by large $\mathrm{O}_{3}$ concentrations (which increases the $\mathrm{NO}_{2}$ oxidation rate) and low losses of $\mathrm{NO}_{3}$ and $\mathrm{N}_{2} \mathrm{O}_{5}$. Figure 11 displays the variation of $F$ on the nights of 13 and 15 May. The amount of reactive nocturnal nitrogen oxides partitioned as $\mathrm{NO}_{3}$ and $\mathrm{N}_{2} \mathrm{O}_{5}$ is initially negligible as the $\mathrm{NO}_{3}$ and $\mathrm{N}_{2} \mathrm{O}_{5}$ lifetimes are short. Only later do $\mathrm{NO}_{3}$ and $\mathrm{N}_{2} \mathrm{O}_{5}$ reach appreciable concentrations, with $F$ reaching a maximum value of $\sim 20 \%$ on 13 and $\sim 15 \%$ on 15 May. The slow build up to larger values of $F$ is due to the small rate coefficient for $\mathrm{NO}_{2}+\mathrm{O}_{3}$ $\left(\sim 2 \times 10^{-17} \mathrm{~cm}^{3}\right.$ molecule $\mathrm{s}^{-1} \mathrm{~s}^{-1}$ at $\left.295 \mathrm{~K}\right)$ resulting in $\mathrm{NO}_{2}$ half lives in the order of hours at $70 \mathrm{ppb} \mathrm{O}_{3}$ and also due to a slow decline in reactivity of $\mathrm{NO}_{3}$ in the early part of the night.

The integrated loss of $\mathrm{NO}_{2}$ (calculated from the $\mathrm{NO}_{2}$ and $\mathrm{O}_{3}$ concentrations and the rate coefficient $k_{1}$ ) is also displayed for the night of 13-14 May in this figure. By the end of the night, about $1.5 \mathrm{ppb}$ of $\mathrm{NO}_{2}$ have been converted via $\mathrm{NO}_{3}$ and $\mathrm{N}_{2} \mathrm{O}_{5}$ to gas-phase and particle phase products.

$\mathrm{NO}_{3}$ and $\mathrm{N}_{2} \mathrm{O}_{5}$ remaining at the end of the night are rapidly converted photolytically/thermally back to $\mathrm{NO}_{2}$ (and, less importantly, NO) at dawn, hence the rapid reduction in $F$ at circa $06: 00$ on the 14 th. On this particular night the nocturnal mean value of $F$ was $\sim 9 \%$. The same value was obtained as average over all nights of the campaign on which there was no precipitation. The average value of $F$ was only $\sim 3 \%$ on the night 15 th-16th, presumably due to efficient loss of $\mathrm{N}_{2} \mathrm{O}_{5}$ on aqueous surfaces. As the lifetimes of $\mathrm{NO}_{3}$ and $\mathrm{N}_{2} \mathrm{O}_{5}$ were much shorter than the duration of the night, and only a small fraction of $\mathrm{NO}_{2}$ that has been converted to $\mathrm{NO}_{3}$ and $\mathrm{N}_{2} \mathrm{O}_{5}$ is converted back to $\mathrm{NO}_{2}$ at dawn, we can assume that all $\mathrm{NO}_{2}$ which was oxidised by $\mathrm{O}_{3}$ at night represents an irreversible loss of $\mathrm{NO}_{\mathrm{x}}$ to either organic or inorganic nitrates. In this case, the loss rate of $\mathrm{NO}_{\mathrm{x}}\left(L_{\mathrm{NOx}}\right)$ is given by:

$L_{\mathrm{NOx}} \approx n \cdot k_{1}\left[\mathrm{NO}_{2}\right]\left[\mathrm{O}_{3}\right]$

where the factor $n$ is 1 if $\mathrm{NO}_{3}$ is lost only directly (e.g. by reaction with VOC) and is 2 if $\mathrm{NO}_{3}$ is lost indirectly via $\mathrm{N}_{2} \mathrm{O}_{5}$ formation and reaction as two $\mathrm{NO}_{2}$ are required to make each $\mathrm{N}_{2} \mathrm{O}_{5}$ molecule. For the present campaign we have shown that $\mathrm{NO}_{3}$ is lost predominantly by direct routes, so that $n$ should be close to 1 .

The daytime loss of $\mathrm{NO}_{\mathrm{x}}$ is dominated by reaction of $\mathrm{NO}_{2}$ with the $\mathrm{OH}$ radical

$\mathrm{OH}+\mathrm{NO}_{2} \rightarrow \mathrm{HNO}_{3}$

with the rate of loss of $\mathrm{NO}_{2}$ via this route approximately given by $k_{8}[\mathrm{OH}]\left[\mathrm{NO}_{2}\right]$, which is also the production rate of $\mathrm{HNO}_{3}$. At the pressure and temperatures prevalent during the campaign, $k_{8}$ has a value of $\sim 1 \times 10^{-11} \mathrm{~cm}^{3}$ molecule ${ }^{-1} \mathrm{~s}^{-1}$. There appears to be only one set of measurements $\mathrm{HNO}_{3}$ mixing ratios at the Taunus Observatory, in which values of $\sim 0.1-1$ ppb were reported in November of 1990 (Fuzzi et al., 1994).

As no $\mathrm{OH}$ measurements were made during the campaign, its concentration was calculated using the parameterisation of Ehhalt and Rohrer (2000). Approximate, time dependent values of $J_{\mathrm{NO} 2}$ were calculated from the measured global radiation using the parameterisation of Trebs et al. (2009). $J_{01 \mathrm{D}}$ was calculated from $J_{\mathrm{NO} 2}$ using relative (solar zenith angle dependent) values taken from the 4.1 version of the NCAR-TUV model (http://cprm.acd.ucar.edu/Models/ TUV/Interactive_TUV/). Maximum peak values for $J_{\mathrm{O} 1 \mathrm{D}}$ and $J_{\mathrm{NO} 2}$ thus derived were $4 \times 10^{-5} \mathrm{~s}^{-1}$ and $9 \times 10^{-3} \mathrm{~s}^{-1}$, respectively, which resulted in peak $\mathrm{OH}$ concentrations of $>1 \times 10^{7}$ molecule $\mathrm{cm}^{-3}$ during the early part of the campaign, decreasing to $\sim 5 \times 10^{6}$ molecule $\mathrm{cm}^{-3}$ during the last days of the campaign when insolation was reduced by clouds. The present measurements of relatively large $\mathrm{O}_{3}$ mixing ratios and previous measurements of peroxy radical mixing ratios of several 10s of pptv in June in previous years at the site (Handisides, 2001) indicate an active photochemistry and imply that these $\mathrm{OH}$ concentrations are reasonable. They are also consistent with daytime measurements of $\mathrm{OH}$ at another forested mountain site under very similar levels of insolation and with comparable levels of $\mathrm{O}_{3}$ (Handisides et al., 2003).

Figure 12 displays calculated rates of $\mathrm{NO}_{2}$ loss (in $\mathrm{ppb} /$ hour) via both reaction with $\mathrm{OH}$ and with $\mathrm{O}_{3}$. during a period of 7 days of the campaign. Night-time losses via reaction of $\mathrm{NO}_{2}+\mathrm{O}_{3}$ are calculated only when global radiation was less than $20 \mathrm{~W} \mathrm{~m}^{-2}$ and $\mathrm{NO}_{2}$ photolysis should be insignificant. At the beginning of the campaign, when insolation was high, daytime $\mathrm{NO}_{2}$ losses $(0.2-1 \mathrm{ppb}$ per hour $)$ 


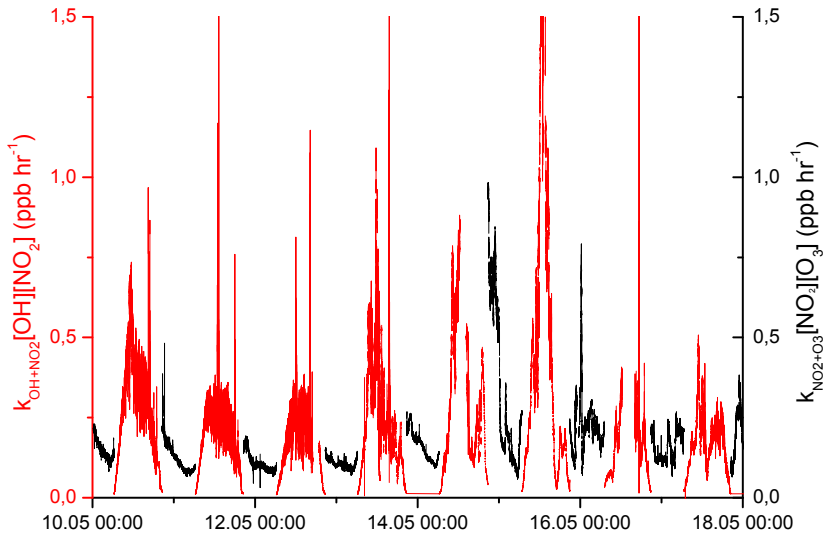

Fig. 12. Daytime $\left(k_{\mathrm{OH}+\mathrm{NO} 2}[\mathrm{OH}]\left[\mathrm{NO}_{2}\right]\right.$, in red $)$ versus night-time $\left(k_{\mathrm{O} 3+\mathrm{NO} 2}\left[\mathrm{O}_{3}\right]\left[\mathrm{NO}_{2}\right]\right.$, in black) loss rates $(\mathrm{ppb} / \mathrm{h})$ of $\mathrm{NO}_{\mathrm{x}}$ at the Taunus Observatorium in May 2008.

dominated (by a factor of $\sim 2-3$ ) over night-time losses. This picture changes for the last days of the campaign, where day and night-time losses were approximately equal at about $0.2 \mathrm{ppb}$ per hour. The simple calculations above show that, at the surface, day- and night-time losses of $\mathrm{NO}_{\mathrm{x}}$ are similar. However, as the ratio of night-time to day-time losses depends on insolation at the site, night-time losses will be favoured still more in the colder months as $\mathrm{O}_{3}$ photolysis and $\mathrm{OH}$ production rate drop significantly. The fact that the night-time boundary layer is shallower than in the daytime will however have the converse effect and favour daytime oxidation. We can conclude that night-time loss of $\mathrm{NO}_{\mathrm{x}}$ due to $\mathrm{NO}_{3}$ (and $\mathrm{N}_{2} \mathrm{O}_{5}$ ) formation is comparable to daytime loss driven by $\mathrm{OH}$ at the Taunus Observatory, confirming speculation that nitrate driven acidity in cloud water at the Kleiner Feldberg could be caused either by $\mathrm{HNO}_{3}$ or $\mathrm{N}_{2} \mathrm{O}_{5}$ uptake (Fuzzi et al., 1994). As vertical profiles of $\mathrm{NO}_{2} / \mathrm{O}_{3}$ etc were not measured, our conclusion applies only to the surface.

Although no VOCs were measured during the campaign, the persistently high night-time mixing ratios of $\mathrm{NO}_{3}$ indicate an important role for the oxidation of VOCs at the site. An average daytime $\mathrm{OH}$ concentrations of $\sim 4 \times 10^{6}$ molecule $\mathrm{cm}^{-3}$ and an average night-time mixing ratio of 10 pptv for $\mathrm{NO}_{3}$ result in a concentration ratio that favours $\mathrm{NO}_{3}$ by a factor of $\sim 60$. The ratios of rate coefficients $\left(k_{\mathrm{OH}} / k_{\mathrm{NO} 3}\right)$ for reaction of $\mathrm{OH}$ and $\mathrm{NO}_{3}$ with isoprene and several monoterpenes favour $\mathrm{OH}$ and may be calculated from reviewed kinetic data (Atkinson and Arey, 2003) as: isoprene (147), $\alpha$-pinene (8.5), limonene (13.4), sabinene (11.7). These numbers indicate that whereas $\mathrm{NO}_{3}$ will contribute significantly to isoprene removal, it would dominate for the mono-terpenes listed above. The simple calculation does not take the diurnal changes in VOC emission rates mixing ratios into account and a more detailed understanding of the relative importance of daytime versus night-time removal of boundary layer $\mathrm{NO}_{\mathrm{x}}$ and the fate of reactive VOCs at this site would require diel measurements of both the major oxidants $\left(\mathrm{OH}\right.$ and $\left.\mathrm{NO}_{3}\right)$ and the VOCs.

\section{Conclusions}

A complete set of nocturnal nitrogen oxides, $\mathrm{O}_{3}$ and aerosol surface area was measured for the first time at the Taunus Observatory. The measurements provided both a test of the new $\mathrm{NO}_{3} / \mathrm{N}_{2} \mathrm{O}_{5}$ instrument and delivered valuable information concerning night-time oxidation at the site. Both $\mathrm{NO}_{3}$ and $\mathrm{N}_{2} \mathrm{O}_{5}$ were present above the detection limits on all nights and the relative concentrations were in accord with the temperature, $\mathrm{NO}_{2}$ and the equilibrium constant for $\mathrm{N}_{2} \mathrm{O}_{5}$ formation and thermal dissociation. The major sink of $\mathrm{NO}_{\mathrm{x}}$ was inferred to be direct loss of $\mathrm{NO}_{3}$ by reaction with biogenic hydrocarbons and nocturnal chemistry at this site was shown to contribute significantly both to the conversion of $\mathrm{NO}_{\mathrm{x}}$ to $\mathrm{NO}_{\mathrm{y}}$ and likely to the oxidation of biogenic VOCs. A steady state analysis was used to estimate direct and indirect losses of $\mathrm{NO}_{3}$ and $\mathrm{N}_{2} \mathrm{O}_{5}$ and revealed shortcomings in the laboratory derived kinetics of the reaction of $\mathrm{N}_{2} \mathrm{O}_{5}$ with water-vapour.

Acknowledgements. We thank Andreas Engel and Albrecht Fester of the Johann Wolfgang Goethe-Universität in Frankfurt for logistical assistance related to equipping the container. We thank the DWD and the HLUG for meteorological measurements and the HLUG for providing information regarding their $\mathrm{O}_{3}$ measurement procedure. Thanks also to Vinayak Sinha and Jonathan Williams at the MPI for sharing their PTRMS dataset obtained at the Kleiner Feldberg.

The service charges for this open access publication have been covered by the Max Planck Society.

Edited by: J. Thornton

\section{References}

Aldener, M., Brown, S. S., Stark, H., Williams, E. J., Lerner, B. M., Kuster, W. C., Goldan, P. D., Quinn, P. K., Bates, T. S., Fehsenfeld, F. C., and Ravishankara, A. R.: Reactivity and loss mechanisms of $\mathrm{NO}_{3}$ and $\mathrm{N}_{2} \mathrm{O}_{5}$ in a polluted marine environment: Results from in situ measurements during New England Air Quality Study 2002, J. Geophys. Res., 111, D23S73, doi:10.1029/2006JD007252, 2006.

Allan, B. J., Carslaw, N., Coe, H., Burgess, R. A., and Plane, J. M. C.: Observations of the nitrate radical in the marine boundary layer, J. Atmos. Chem., 33, 129-154, 1999.

Allan, B. J., McFiggans, G., Plane, J. M. C., Coe, H., and McFadyen, G. G.: The nitrate radical in the remote marine boundary layer, J. Geophys. Res., 105, 24191-24204, 2000.

Ambrose, J. L., Mao, H., Mayne, H. R., Stutz, J., Talbot, R., and Sive, B. C.: Night-time nitrate radical chemistry at Appledore island, Maine during the 2004 international consortium for atmospheric research on transport and transformation, J. Geophys. Res., 112, D21302, doi:101.1029/2007JD008756, 2007. 
Apodaca, R. L., Simpson, W. R., Brauers, T., Brown, S. S., Cohen, R. C., Crowley, J., Dorn, H. P., Dubé, W. P., Fry, J., Fuchs, H., Haseler, R., Heitmann, U., Kato, S., Kajii, Y., Kiendler-Scharr, A., Labazan, I., Matsumoto, J., Nishida, S., Tillmann, R., Rohrer, F., Rollings, A.W., Schlosser, E., Schuster, G., Tillmann, R., Wahner, A., Wegener, R., and Wooldridge, P. J.: Intercomparison of $\mathrm{N}_{2} \mathrm{O}_{5}$ sensors using the SAPHIR reaction chamber, Atmos. Chem. Phys. Discusss., in preparation, 2010.

Atkinson, R. and Arey, J.: Atmospheric degradation of volatile organic compounds, Chem. Rev., 103, 4605-4638, 2003.

Atkinson, R., Baulch, D. L., Cox, R. A., Crowley, J. N., Hampson, R. F., Hynes, R. G., Jenkin, M. E., Rossi, M. J., and Troe, J.: Evaluated kinetic and photochemical data for atmospheric chemistry: Volume $\mathrm{I}$ - gas phase reactions of $\mathrm{O}_{\mathrm{x}}, \mathrm{HO}_{\mathrm{x}}, \mathrm{NO}_{\mathrm{x}}$ and $\mathrm{SO}_{\mathrm{x}}$ species, Atmos. Chem. Phys., 4, 1461-1738, 2004, http://www.atmos-chem-phys.net/4/1461/2004/.

Berden, G., Peeters, R., and Meijer, G.: Cavity ring-down spectroscopy: Experimental schemes and applications, Int. Rev. Phys. Chem., 19, 565-607, 2000.

Brown, S. S., Dube, W. P., Fuchs, H., Ryerson, T. B., Wollny, A. G., Brock, C. A., Bahreini, R., Middlebrook, A. M., Neuman, J. A., Atlas, E., Roberts, J. M., Osthoff, H. D., Trainer, M., Fehsenfeld, F. C., and Ravishankara, A. R.: Reactive uptake coefficients for $\mathrm{N}_{2} \mathrm{O}_{5}$ determined from aircraft measurements during the Second Texas Air Quality Study: Comparison to current model parameterizations, J. Geophys. Res., 114, D00F10, doi:10.1029/2008JD011679, 2009.

Brown, S. S., Dubé, W. P., Osthoff, H. D., Wolfe, D. E., Angevine, W. M., and Ravishankara, A. R.: High resolution vertical distributions of $\mathrm{NO}_{3}$ and $\mathrm{N}_{2} \mathrm{O}_{5}$ through the nocturnal boundary layer, Atmos. Chem. Phys., 7, 139-149, 2007, http://www.atmos-chem-phys.net/7/139/2007/.

Brown, S. S., Ryerson, T. B., Wollny, A. G., Brock, C. A., Peltier, R., Sullivan, A. P., Weber, R. J., Dube, W. P., Trainer, M., Meagher, J. F., Fehsenfeld, F. C., and Ravishankara, A. R.: Variability in nocturnal nitrogen oxide processing and its role in regional air quality, Science, 311, 67-70, 2006.

Brown, S. S., Stark, H., and Ravishankara, A. R.: Applicability of the steady state approximation to the interpretation of atmospheric observations of $\mathrm{NO}_{3}$ and $\mathrm{N}_{2} \mathrm{O}_{5}$, J. Geophys. Res., 108, 4539, doi:10.1029/2003JD003407, 2003a.

Brown, S. S., Stark, H., Ryerson, T. B., Williams, E. J., Nicks, D. K., Trainer, M., Fehsenfeld, F. C., and Ravishankara, A. R.: Nitrogen oxides in the nocturnal boundary layer: Simultaneous in situ measurements of $\mathrm{NO}_{3}, \mathrm{~N}_{2} \mathrm{O}_{5}, \mathrm{NO}_{2}, \mathrm{NO}$, and $\mathrm{O}_{3}$, J. Geophys. Res., 108, 4299, doi:10.1029/2002JD002917, 2003b.

Curtis, A. R. and Sweetenham, W. P.: Facsimile, AERE, Report R-12805, 1987.

Dorn, H. P., Apodaca, R. L., Ball, S. M., Brauers, T., Brown, S. S., Crowley, J. N., Dube, W. P., Fuchs, H., Häseler, R., Heitmann, U., Jones, R. L., Labazan, I., Langridge, J., Meinen, J., Platt, U., Pöhler, D., Rohrer, F., Ruth, A. A., Schlosser, E., Schuster, G., Shillings, A., Simpson, W., Thieser, J., Varma, R., Venables, D., and Wahner, A.: Intercomparison of $\mathrm{NO}_{3}$ radical detection instruments in the Atmosphere Simulation Chamber SAPHIR., Atmos. Chem. Phys. Discuss., in preparation, 2010.

Ehhalt, D. H. and Rohrer, F.: Dependence of the $\mathrm{OH}$ concentration on solar UV, J. Geophys. Res., 105, 3565-3571, 2000.

Fehsenfeld, F., Calvert, J., Fall, R., Goldan, P., Guenther, A., He- witt, C.N., Lamb, B., Liu, S., Trainer, M., Westberg, H., and Zimmerman, P.: Emissions of volatile organic compounds from vegetation and the implications for atmospheric chemistry, Global Biogeochem. Cycles, 6, 389-430, 1992.

Folkers, M., Mentel, T. F., and Wahner, A.: Influence of an organic coating on the reactivity of aqueous aerosols probed by the heterogeneous hydrolysis of $\mathrm{N}_{2} \mathrm{O}_{5}$, Geophys. Res. Lett., 30, 1644, doi:10.1029/2003GL017168, 2003.

Fontijn, A., Sabadell, A. J., and Ronco, R. J.: Homogeneous chemiluminescent measurement of nitric oxide with ozone - Implications for continuous selective monitoring of gaseous air pollutants, Anal. Chem., 42, 575-579, 1970.

Fuzzi, S., Facchini, M. C., Schell, D., Wobrock, W., Winkler, P., Arends, B. G., Kessel, M., Mols, J. J., Pahl, S., Schneider, T., Berner, A., Solly, I., Kruisz, C., Kalina, M., Fierlinger, H., Hallberg, A., Vitali, P., Santoli, L., and Tigli, G.: Multiphase Chemistry and Acidity of Clouds at Kleiner-Feldberg, J. Atmos. Chem., 19, 87-106, 1994.

Geyer, A., Alicke, B., Konrad, S., Schmitz, T., Stutz, J., and Platt, U.: Chemistry and oxidation capacity of the nitrate radical in the continental boundary layer near Berlin, J. Geophys. Res., 106, 8013-8025, 2001.

Geyer, A. and Platt, U.: Temperature dependence of the $\mathrm{NO}_{3}$ loss frequency: A new indicator for the contribution of $\mathrm{NO}_{3}$ to the oxidation of monoterpenes and NOx removal in the atmosphere, J. Geophys. Res., 107, 4431, doi:10.1029/2001JD001215, 2002.

Hallquist, M., Stewart, D. J., Baker, J., and Cox, R. A.: Hydrolysis of $\mathrm{N}_{2} \mathrm{O}_{5}$ on submicron sulfuric acid aerosols, J. Phys. Chem. A, 104, 3984-3990, 2000.

Handisides, G. M.: The influence of peroxy radicals on ozone production, PhD thesis, Johann Wolfgang Goethe Universität, Fachbereich Geowissenschaften, Frankfurt am Main, 2001.

Handisides, G. M., Plass-Dlmer, C., Gilge, S., Bingemer, H., and Berresheim, H.: Hohenpeissenberg Photochemical Experiment (HOPE 2000): Measurements and photostationary state calculations of $\mathrm{OH}$ and peroxy radicals, Atmos. Chem. Phys., 3, 15651588, 2003, http://www.atmos-chem-phys.net/3/1565/2003/.

Heintz, F., Platt, U., Flentje, H., and Dubois, R.: Long-term observation of nitrate radicals at the tor station, Kap Arkona (Rugen), J. Geophys. Res., 101, 22891-22910, 1996.

IUPAC, Subcommittee for gas kinetic data evaluation (Ammann, M., Atkinson, R., Cox, R. A., Crowley, J. N., Hynes, R. G., Jenkin, M. E., Mellouki, W., Rossi, M. J., Troe, J., and Wallington, T. J.): Evaluated kinetic data: http://www.iupac-kinetic.ch. cam.ac.uk/, 2009.

Kley, D. and McFarland, M.: Chemiluminescence detector for NO and $\mathrm{NO}_{2}$, Atmos. Technol., 12, 63-69, 1980.

Kraus, A. and Hofzumahaus, A.: Field measurements of atmospheric photolysis frequencies for $\mathrm{O}_{3}, \mathrm{NO}_{2}, \mathrm{HCHO}, \mathrm{CH}_{3} \mathrm{CHO}$ hooh, and HONO by UV spectroradiometry, J. Atmos. Chem. 31, 161-180, 1998.

Mazurenka, M., Orr-Ewing, A. J., Peverall, R., and Ritchie, G. A. D.: Cavity ring-down and cavity enhanced spectroscopy using diode lasers, Annu. Rep. Prog. Chem., Sect C, 101, 100-142, 2005.

Orphal, J., Fellows, C. E., and Flaud, P. M.: The visible absorption spectrum of $\mathrm{NO}_{3}$ measured by high-resolution Fourier transform spectroscopy, J. Geophys. Res., 108, 4077, 
doi:10.1029/2002JD002489, 2003.

Osthoff, H. D., Pilling, M. J., Ravishankara, A. R., and Brown, S. S.: Temperature dependence of the $\mathrm{NO}_{3}$ absorption cross-section above $298 \mathrm{~K}$ and determination of the equilibrium constant for $\mathrm{NO}_{3}+\mathrm{NO}_{2}<->\mathrm{N}_{2} \mathrm{O}_{5}$ at atmospherically relevant conditions, Phys. Chem. Chem. Phys., 9, 5785-5793, 2007.

Ridley, B. A., Grahek, F. E., and Walega, J. G.: A small, highsensitivity, medium-response ozone detector suitable for measurements from light aircraft, J. Atmos. Ocean. Technol., 9, 142148, 1992.

Sander, S. P., Friedl, R. R., Golden, D. M., Kurylo, M. J., Huie, R. E., Orkin, V. L., Moortgat, G. K., Ravishankara, A. R., Kolb, C. E., Molina, M. J., and Finlayson-Pitts, B. J.: Chemical Kinetics and Photochemical Data for Use in Atmospheric Studies, Evaluation Number 14, Jet Propulsion Laboratory, National Aeronautics ans Space Administration/Jet Propulsion Laboratory/California Institute of Technology, Pasadena, CA, 2003.

Sander, S. P., Friedl, R. R., Golden, D. M., Kurylo, M. J., Huie, R. E., Orkin, V. L., Moortgat, G. K., Ravishankara, A. R., Kolb, C. E., Molina, M. J., and Finlayson-Pitts, B. J.: Chemical kinetics and photochemical data for use in atmospheric studies: Evaluation Number 15, Jet Propulsion Laboratory, National Aeronautics and Space Administration/Jet Propulsion Laboratory/California Institute of Technology, Pasadena, CA, 2006.
Schuster, G., Labazan, I., and Crowley, J. N.: A cavity ring down/cavity enhanced absorption device for measurement of ambient $\mathrm{NO}_{3}$ and $\mathrm{N}_{2} \mathrm{O}_{5}$, Atmos. Meas. Tech., 2, 1-13, 2009, http://www.atmos-meas-tech.net/2/1/2009/.

Trebs, I., Bohn, B., Ammann, C., Rummel, U., Blumthaler, M., Königstedt, R., Meixner, F. X., Fan, S., and Andreae, M. O.: Relationship between the $\mathrm{NO}_{2}$ photolysis frequency and the solar global irradiance, Atmos. Meas. Tech., 2, 725-739, 2009, http://www.atmos-meas-tech.net/2/725/2009/.

Wayne, R. P., Barnes, I., Biggs, P., Burrows, J. P., Canosa-Mas, C. E., Hjorth, J., Le Bras, G., Moortgat, G. K., Perner, D., Poulet, G., Restelli, G., and Sidebottom, H.: The nitrate radical: Physics, chemistry, and the atmosphere, Atmos. Environ., 25A, 1-206, 1991.

Wetter, T.: Eine Untersuchung zur Charakterisierung der Zeitlichen Variabilität det luftchemischen Bedingungen am TaunusObservatorium: Messungen des $\mathrm{CO}$ und $\mathrm{H}_{2}$ Mischverhältnises im Winter 1996/7, Johan Wolfgang Goethe-Universität, Fachbereich Geowissenschaft, Frankfurt am Main, 1998.

Yokelson, R. J., Burkholder, J. B., Fox, R. W., Talukdar, R. K., and Ravishankara, A. R.: Temperature-dependence of the $\mathrm{NO}_{3}$ absorption-Spectrum, J. Phys. Chem., 98, 13144-13150, 1994. 